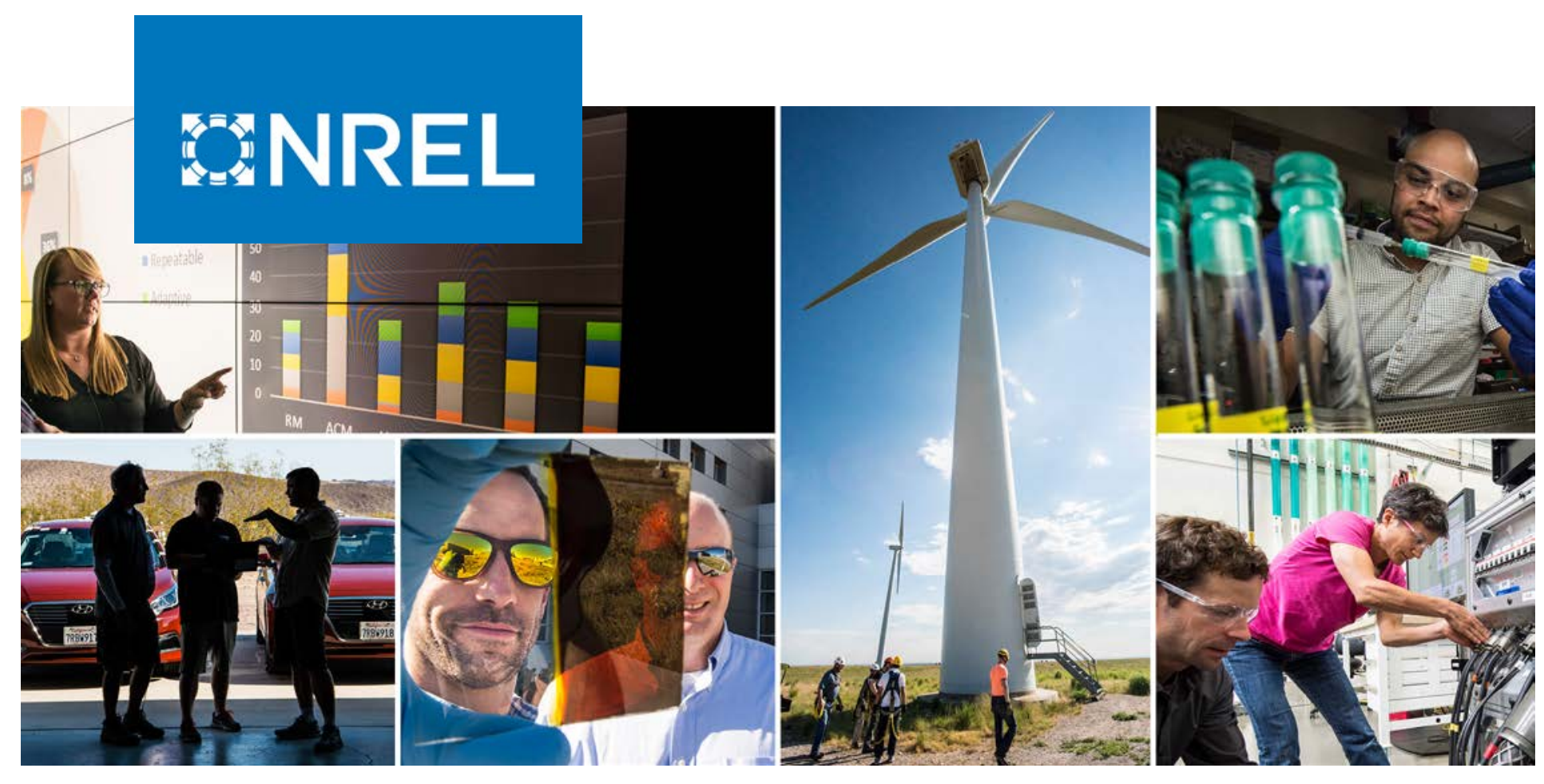

\title{
Manufacturing and Reliability Science for CIGS Photovoltaics
}

\author{
Lorelle Mansfield
}

National Renewable Energy Laboratory

NREL is a national laboratory of the U.S. Department of Energy

Office of Energy Efficiency \& Renewable Energy

Operated by the Alliance for Sustainable Energy, LLC

This report is available at no cost from the National Renewable Energy Laboratory (NREL) at www.nrel.gov/publications.
Technical Report

NREL/TP-5K00-72953

January 2019 


\title{
GNREL
}

\section{Manufacturing and Reliability Science for CIGS Photovoltaics}

\author{
Lorelle Mansfield
}

National Renewable Energy Laboratory

\section{Suggested Citation}

Mansfield, Lorelle. 2019. Manufacturing and Reliability Science of CIGS Photovoltaics.

Golden, CO: National Renewable Energy Laboratory. NREL/TP-5K00-72953.

https://www.nrel.gov/docs/fy19osti/72953.pdf.

NREL is a national laboratory of the U.S. Department of Energy Office of Energy Efficiency \& Renewable Energy Operated by the Alliance for Sustainable Energy, LLC

This report is available at no cost from the National Renewable Energy Laboratory (NREL) at www.nrel.gov/publications.

Contract No. DE-AC36-08GO28308
Technical Report NREL/TP-5K00-72953 January 2019

National Renewable Energy Laboratory 15013 Denver West Parkway Golden, CO 80401

303-275-3000 • www.nrel.gov 


\section{NOTICE}

This work was authored by the National Renewable Energy Laboratory, operated by Alliance for Sustainable Energy, LLC, for the U.S. Department of Energy (DOE) under Contract No. DE-AC36-08G028308. Funding provided by U.S. Department of Energy Office of Energy Efficiency and Renewable Energy Solar Energy Technologies Office. The views expressed herein do not necessarily represent the views of the DOE or the U.S. Government.

This report is available at no cost from the National Renewable Energy Laboratory (NREL) at www.nrel.gov/publications.

U.S. Department of Energy (DOE) reports produced after 1991 and a growing number of pre-1991 documents are available free via www.OSTI.gov.

Cover Photos by Dennis Schroeder: (clockwise, left to right) NREL 51934, NREL 45897, NREL 42160, NREL 45891, NREL 48097, NREL 46526.

NREL prints on paper that contains recycled content. 


\section{Final Report}

Project Title: Manufacturing and Reliability Science for CIGS Photovoltaics

Project Period: $\quad 1$ Oct $2015-30$ Sept 2018

Project Budget: $\quad \$ 4,000,000$

Submission Date: $\quad 30$ September 2018

Recipient: NREL

Address:

15013 Denver West Pkwy., Golden, CO 80401

Agreement Number: $\quad$ SuNLaMP 30296

Awarding Agency: DOE EERE SETO PV subprogram

Working Partners: NA

Principal Investigator: Lorelle Mansfield

Scientist

Phone: 303-384-7884

Email: lorelle.mansfield@nrel.gov 
Executive Summary: The purpose of this program was to overcome the largest challenges to investor confidence and long product lifetime in Culn $\times \mathrm{Ga}_{1-\mathrm{x}} \mathrm{Se}_{2}$ (CIGS)based photovoltaic products: metastability, shading-induced hot spots, and potentialinduced degradation (PID). Key findings were made in each of these areas by studying CIGS reliability at the cell level, which very few groups are currently doing. Metastability was thought to be a function of the CIGS absorber. We have challenged the state-of-theart by showing that the metastability seen in commercial products is likely to be caused by the buffer layer. Solar Cell Capacitance Simulator (SCAPS) device modeling confirmed that the buffer layer has a significant influence on metastability in CIGS devices, and it also led to a processing change-the introduction of $\mathrm{CdS}$ islands to $\mathrm{Zn}(\mathrm{O}, \mathrm{S})$ buffer layers-that dramatically reduced metastability in CIGS solar cells. In the reverse-bias shading task, modeling showed us that $19 \%$ solar cells are possible with thin CIGS layers of $0.5 \mu \mathrm{m}$. We were able to fabricate $15.2 \%$ solar cells in this project, which is the highestreported efficiency of devices in the ultra-thin class. We also discovered that the best way to dissipate less power in reverse bias was to eliminate the intrinsic $\mathrm{ZnO}$ layer that is often used in CIGS devices. Lower power dissipation led to devices that allowed two times the maximum power-point current density in reverse without damage. PID is caused by the drift of $\mathrm{Na}+$ ions from the back glass to the CIGS/Mo interface, followed by diffusion into the solar cells and to the CdS region. We found that PID can be slowed by using lowconductivity borosilicate glass that contains higher $\mathrm{K}$ and lower $\mathrm{Na}$ than soda-lime glass. Based on significant progress in each of the three reliability challenges, the CIGS celllevel reliability project was very successful. We have also proved that module-level degradation mechanisms can be tested and solved at the cell level.

Background: The novelty of this work is evidenced by the few updates in the literature in the field of cell-level reliability. Of the three areas of study, metastability has the most activity. Several papers document techniques for measuring metastability, such as photoluminescence [7-10]. Most cite the Lany-Zunger $\mathrm{V}_{\mathrm{se}}-\mathrm{V}_{\mathrm{Cu}}$ complex (LZ) [11] as an absorber defect that is likely responsible for metastable behavior. These are different from our work because we have shown the metastable behavior to be more buffer-related than absorber-related. Some studies did look at buffer changes such as surface treatments [12] and varying chemistry [13-15] to reduce metastability in devices with $\mathrm{Zn}(\mathrm{O}, \mathrm{S})$ buffers. Oftentimes they still site the LS model for defect states in the CIGS at the buffer/absorber interface. One notable experiment is the addition of Si to the CIGS growth [16], which enables the elimination of the buffer layer and also reduces metastability.

Studies related to partial-shading damage include those by Steve Johnston's project, where sites likely to break down were identified using thermal imaging techniques [1719]. Another group looked at differences in reverse breakdown behavior depending on the buffer layer used and modeled it according to Fowler-Nordheim tunneling and also Poole-Frenkel conduction [20]. They think that Fowler-Nordheim tunneling is the main contributor to the breakdown current. This paper could be useful when we begin device modeling for reverse-bias behavior. Of course, there are also reports of partial-shading damage in modules [21, 22], and Marco Nardone was able to model the difference between bare and encapsulated modules [23]. Experimentally, we have shown that encapsulated devices break down at smaller reverse voltages, but that will not be reported publicly. Studies on ultra-thin devices are covered below in the Project Results and Discussion under Task 2. 
Potential-induced degradation (PID) had few literature reports, and we are the main group studying it at the cell level. Several deal with PID test procedures for modules [24-26], documentation of failure in CdTe [27], and a review of module PID [28]. In-situ dark current-voltage measurements were performed on our cells, and maximum power calculations were done similar to reference [29] with the results submitted to the IEEE Journal of Photovoltaics for publication [30].

Introduction: As costs of Si-based modules have dropped rapidly, the projected large price advantage of CIGS over Si has not been realized. Without a substantial price difference between $\mathrm{Si}$ and CIGS modules, and long product lifetime required to achieve low levelized cost of electricity (LCOE), investors have little incentive to choose CIGS, the less mature technology. Thus, with a short product history, addressing product lifetime and reliability issues (or perceived reliability issues) is critical for CIGS. This program was significant because it investigated the three main challenges for reliability in CIGS modules. They correspond to the project tasks: Task 1: Metastability, Task 2: ReverseBias Shading, and Task 3: Potential-Induced Degradation. We took an innovative approach by investigating module-scale problems at the cell level and attempting to solve the problems at the cell level. We found ways to mitigate all three reliability challenges, and they are detailed in the Project Results and Discussion section. The project milestones are listed in Table 1. 


\begin{tabular}{|c|c|c|c|c|c|}
\hline 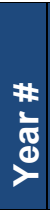 & 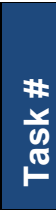 & 尝 & $\begin{array}{l}\text { Milestone } \\
\text { Description }\end{array}$ & $\begin{array}{l}\text { Planned } \\
\text { End Date }\end{array}$ & $\begin{array}{l}\text { Milestone } \\
\text { Type: } \\
\text { Annual or } \\
\text { Quarterly }\end{array}$ \\
\hline 1 & 1 & 1 & $\begin{array}{l}\text { Outline for publication that draws conclusion whether datasets } \\
\text { are consistent with hypothesis that metastability is controlled by } \\
\text { the density of }\left(\mathrm{V}_{\mathrm{Se}}-\mathrm{V}_{\mathrm{Cu}}\right) \text { defects and their population. }\end{array}$ & $3 / 31 / 2016$ & Quarterly \\
\hline 1 & 3 & 2 & $\begin{array}{l}\text { Demonstrate that small-cell module test coupons show no } \\
\text { degradation under standard damp-heat test }\left(85^{\circ} \mathrm{C}, 85 \% \text { relative }\right. \\
\text { humidity, } 1000 \text { hours }) \text { and have electrical leads appropriate for } \\
\text { PID stress and electrical testing. }\end{array}$ & $6 / 30 / 2016$ & Quarterly \\
\hline 1 & 2 & 3 & $\begin{array}{l}\text { Demonstrate an improved state-of-the-art thin device exhibiting } \\
\geq 15 \% \text { efficiency at } \leq 0.5-\mu \mathrm{m} \text { CIGS absorber thickness. Device } \\
\text { should exhibit larger reverse current flow at a fixed reverse } \\
\text { voltage compared to the standard } 2.5-\mu \mathrm{m} \text {-thick device. } \\
\text { Quantify, on a research-cell scale, the magnitude of metastability } \\
\text { and PID in CIGS devices, and identify routes to mitigate these } \\
\text { effects. }\end{array}$ & $9 / 30 / 2016$ & Annual \\
\hline 2 & 1 & 1 & $\begin{array}{l}\text { Identify at least one CIGS metastability mechanism by } \\
\text { demonstrating at least one absorber-processing variation and at } \\
\text { least one buffer-processing variation that significantly affects } \\
\text { metastability. }\end{array}$ & $12 / 31 / 2016$ & Quarterly \\
\hline 2 & 2 & 2 & $\begin{array}{l}\text { Using unencapsulated scribed partner absorbers, document } \\
\text { individual cell voltage at which damage from shading occurs, i.e., } \\
\text { V damage. }\end{array}$ & $3 / 31 / 2017$ & Quarterly \\
\hline 2 & 3 & 3 & $\begin{array}{l}\text { Identify at least two populations resulting in differing amounts of } \\
\text { PID in CIGS cells. }\end{array}$ & $6 / 30 / 2017$ & Quarterly \\
\hline 2 & 2 & 4 & $\begin{array}{l}\text { Demonstrate high-efficiency }(\geq 15 \%) \text { research cell that flows at } \\
\text { least } I_{m p} \text { in reverse current at a reverse voltage bias of } V_{\text {damage }} \text { or } \\
\text { less. } \\
\text { Submit at least three publications to peer-reviewed journals. }\end{array}$ & $9 / 30 / 2017$ & Annual \\
\hline 3 & 2 & 1 & $\begin{array}{l}\text { Using encapsulated NREL cells, document individual cell reverse } \\
\text { voltage at which damage from shading occurs, } V_{\text {damage, }} \text { and } \\
\text { current density allowed before damage occurs. }\end{array}$ & $12 / 31 / 2017$ & Quarterly \\
\hline 3 & 1 & 2 & $\begin{array}{l}\text { Show that buffer metastability is reduced in devices with } \mathrm{Cd} \\
\text { partial-electrolyte }(\mathrm{CdPE}) \text { treatment plus } \mathrm{Zn}(\mathrm{O}, \mathrm{S}) \text { buffer layer } \\
\text { when compared to devices with only a } \mathrm{Zn}(\mathrm{O}, \mathrm{S}) \text { buffer layer. }\end{array}$ & $3 / 31 / 2018$ & Quarterly \\
\hline 3 & 3 & 3 & $\begin{array}{l}\text { Confirm the hypothesis that migrating } \mathrm{Na} \text { is the cause of PID and } \\
\text { that } \mathrm{K} \text { mitigates PID because it migrates less than } \mathrm{Na} \text {. Stress } \\
\text { samples with at least three different alkali levels or incorporation } \\
\text { methods, including at least one K-containing sample and one } \mathrm{Na} \text { - } \\
\text { containing sample. }\end{array}$ & $6 / 30 / 2018$ & Quarterly \\
\hline
\end{tabular}




\begin{tabular}{|c|c|c|c|c|c|}
\hline 3 & 1 & 4 & $\begin{array}{l}\text { Provide specific process and device design guidelines to } \\
\text { eliminate or significantly reduce metastability, shading } \\
\text { degradation, and PID in CIGS. Two out of three of the following } \\
\text { metrics should be achieved: } \\
\text { - (Task 1) Reduce metastability to a change in Voc less than or } \\
\text { equal to } 1 \mathrm{mV} \text { over the time period of } 500 \mathrm{~s} \text { to } 1200 \mathrm{~s} \text { of light } \\
\text { soaking. State-of-the-art: The most-stable devices with } \\
\text { Zn(O,S) buffers had a change in Voc of } 1.8 \mathrm{mV} \text { to } 2.5 \mathrm{mV} \text { over } \\
\text { the time period of } 500 \mathrm{~s} \text { to } 1200 \mathrm{~s} \text { of light soaking. } \\
\text { - (Task } 2 \text { ) Encapsulated devices should allow } 1.5 \mathrm{x} \text { MPP to flow } \\
\text { in reverse-bias without damage. State-of-the-art: Greater than } \\
62 \% \text { of encapsulated mini-modules were damaged by reverse } \\
\text { currents less than } 1.5 \mathrm{x} \text { JMPP. To measure progress, the } \\
\text { behavior of encapsulated standard NREL devices will be } \\
\text { measured in Q1. } \\
\text { - Task } 3 \text { ) Limit PID to } 7 \% \text { relative change in efficiency after } 25 \\
\text { hours of accelerated stressing in the most damaging } \\
\text { configuration of back-grounded with }+1000 \mathrm{~V} \text { applied to } \\
\text { devices. State-of-the-art: Devices on soda-lime glass degrade } \\
\text { by } 100 \% \text { (from original efficiency to } 0 \% \text { efficiency) after } 25 \\
\text { hours of accelerated stressing in the most damaging } \\
\text { configuration. } \\
\text { Publication and/or documentation of communication of these } \\
\text { results to an industrial partner, preferably, with results on } \\
\text { implementation. }\end{array}$ & $9 / 30 / 2018$ & Annual \\
\hline
\end{tabular}




\section{Project Results and Discussion:}

\section{Task 1 Metastability - Summary}

Some commercial CIGS modules show large changes in current-voltage (JV) parameters with light soaking. Although such changes do not necessarily indicate a performance problem, the associated uncertainty may be disadvantageous in a highly competitive market. Thus, it is beneficial to understand the origin of large metastabilities to define what processing changes might diminish metastability without impacting other desirable aspects of high-performance devices. We have attempted to reproduce large metastabilities such as those in some commercial products through both absorber and buffer processing variations in small devices. Although variations of both types were found to affect metastability, only buffer variations could reproduce large metastability in high-efficiency devices. Device modeling confirms that buffer effects alone are sufficient to explain the large metastability seen in these devices. The device model has guided us toward a processing change that reduces metastability without increasing current loss in the buffer.

\section{Background}

In CIGS cells and modules, changes in JV behavior with light exposure are most typically observed to be metastable, (i.e., the change can be reversed by periods of dark storage) and positive (i.e., module efficiency increases with time). Some products are observed to undergo large metastable increases in fill factor and voltage with light exposure. Figure 1 shows an example of parameter changes with light soaking in a commercial CIGS module. JV parameters are shown as a function of one-sun light-soaking time at $50^{\circ} \mathrm{C}$.

\section{Buffer Variations}

Several works have reported larger JV metastability in CIGS with non-CdS buffers compared to CdS buffers [3135]. Results from this study support that trend. Figure 2 shows the change in opencircuit voltage $\left(\mathrm{V}_{\mathrm{oc}}\right)$ with light soaking for an experiment involving only buffer variations. Data from all 45 different samples are shown, with the mean value for each buffer type marked with an "X."

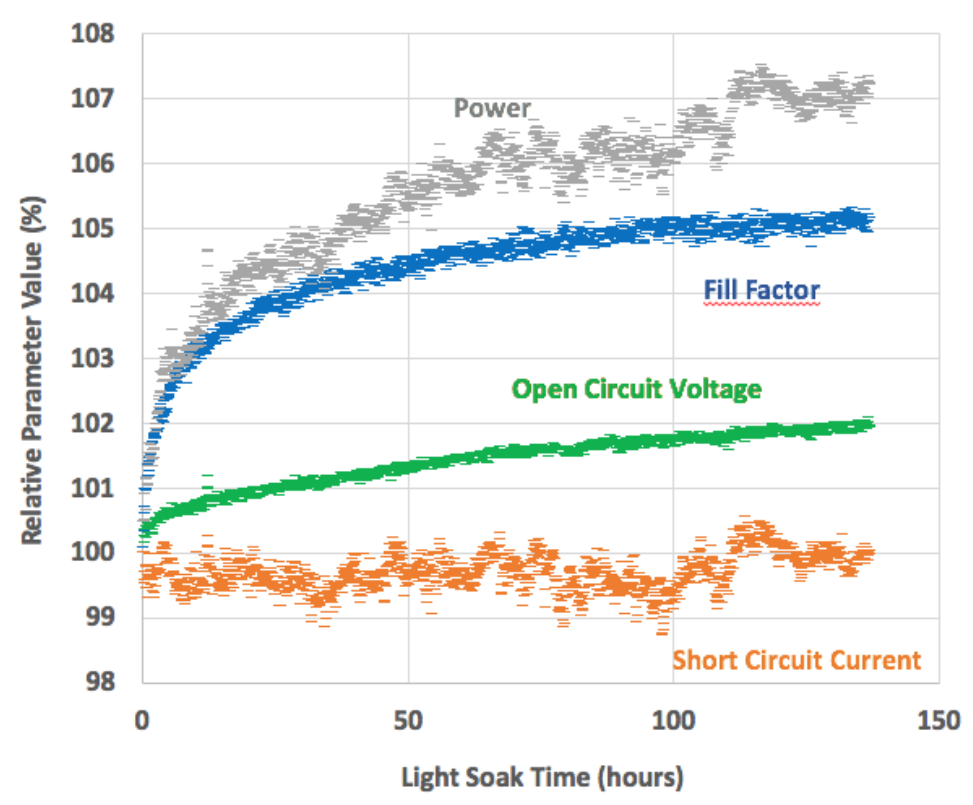

Figure 1: Power, $V_{o c}$, and fill factor as a function of 1-sun light-soak time for an example of a commercial CIGS module. 


\section{Absorber Variations}

The goal was to induce large metastable device behavior via multiple variations in absorber processing, without changing the CdS buffer. 37 samples incorporating processing variations were expected to affect metastable defect concentration. However, for high-efficiency samples (i.e., efficiency $\geq 15 \%$ ), large metastability did not occur. This result is shown by the gray + signs in Figure 3. On the other hand, some absorber process variations resulted in low-efficiency devices with significant metastability. The low-efficiency, metastable devices occurred for process variations that produced low carrier density. The black circles in Figure 3, read to the bottom axis, show how the metastable change in $V_{\text {oc }}$ anticorrelates with zero-bias, dark-state carrier density (p).

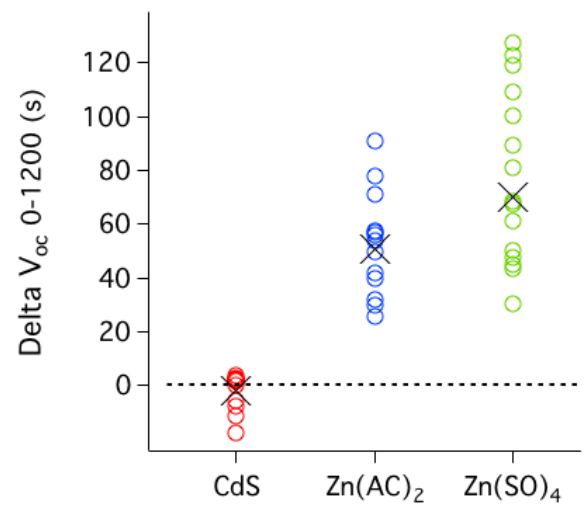

Figure 2: Voltage metastability in CIGS devices for different buffer deposition chemistries, with mean value marked as " $X$."
An anti-correlation between carrier density and metastable change in $\mathrm{V}_{\text {oc }}$ is to be expected from the modest metastable defect concentrations reported. Specifically, following the derivation of Obereigner, the change in $\mathrm{V}_{\text {oc, }} \Delta \mathrm{V}_{\text {oc }}$, can be derived to be

$$
\Delta V_{o c} \approx \frac{A k T}{2 q} \ln \left(1+\frac{\Delta p_{\text {meta }}}{p_{\text {shallow }}}\right),
$$

where $\mathrm{k}$ is Boltzmann's constant, $\mathrm{T}$ is temperature, $\mathrm{q}$ is the electron charge, $A$ is the diode quality factor, pshallow is the shallow acceptor density, and $\Delta p_{\text {meta }}$ is the change with light-soaking and a subsequent increase with light soaking due to metastable defects. The solid line in Figure 3 is a least-squares fit using the form of this equation and Pmeta as the fit parameter. The extracted value for $\Delta$ pmeta is $8.5 \times 10^{14}$ $\mathrm{cm}^{-3}$, in approximate agreement with the low $10^{15} \mathrm{~cm}^{-3}$ values of $\Delta$ pmeta observed in the literature. The correlation coefficient is 0.6 , implying that this relationship explains most of the variation in metastability in the dataset.

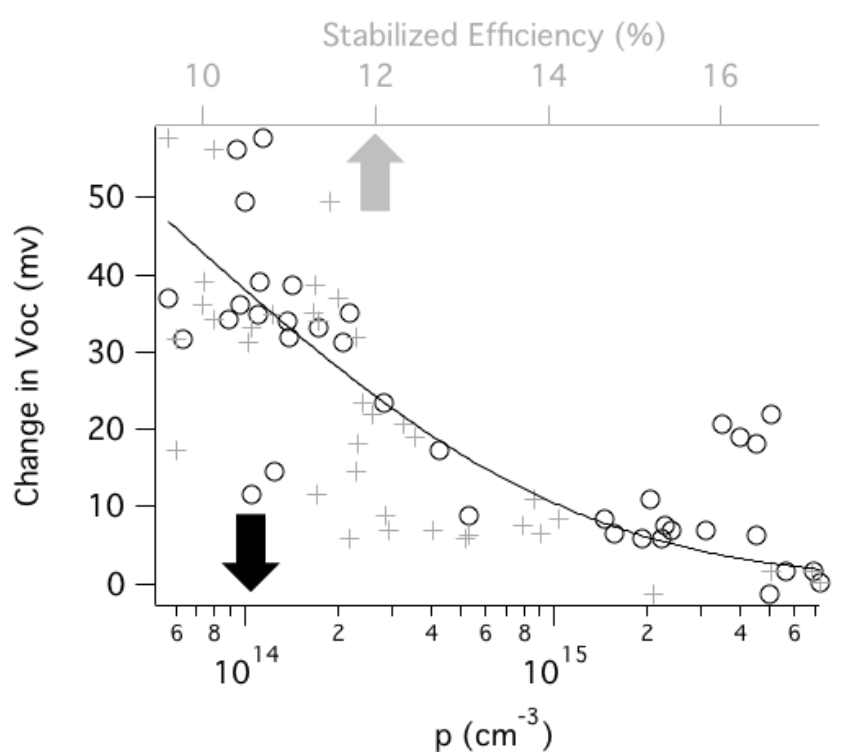

Figure 3: Metastable change in $V_{o c}$ as a function of dark carrier density (lower axis, black circles) or stabilized device efficiency (upper axis, gray +'s). The solid line is a least-squares fit to the carrier-density data. 
JV Curves and Device Modeling of Buffer Variations

JV curves exhibiting metastability were modeled to determine what ranges of materials parameters might reasonably lead to the observed effects. A few representative JV curves from this study were chosen for modeling and are shown in Figure 4 as solid lines. Because the CdS devices are much more stable, Figure 4 contains only one experimental $\mathrm{JV}$ curve for this device, whereas both relaxed-state and light-soaked curves are shown for the other devices.

Device modeling was used to understand the possible origins of the observed behaviors, using Solar Cell Capacitance Simulator (SCAPS)

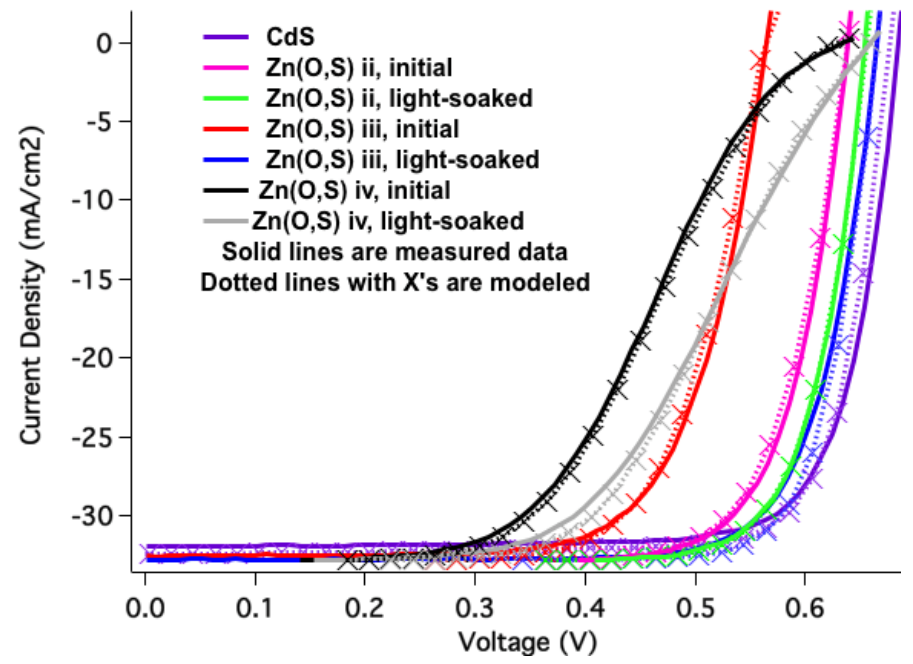

Figure 4: Measured JV curves (solid lines) and modeled $J V$ curves (dashed lines with $x$ 's) for samples with different buffer variations.

software [36]. Literature or measured materials properties values were used to describe each layer. The values employed in the SCAPS model are well-documented in the paper (drafted, to be submitted) so that other groups may use them to replicate our results and compare to their own devices. Four ZnOS parameters-free-electron density, deep-trap density, buffer/absorber surface recombination velocity, and buffer/absorber conductionband offset-were varied to fit the experimental JV curves. These modeled JV curves are overlaid with the experimental data in Figure 4. The modeled curves reproduce the features of the experimental data (including inflection, voltage, and fill factor increases with light soaking) and curve shape. Thus, it is concluded that buffer effects alone are sufficient to explain the large metastability seen in these devices. 
Implications for Processing Changes

The insights provided by the SCAPS device model have suggested some processing changes that might mitigate metastability. One such change has been proven experimentally. Tiny islands of CdS were deposited adjacent to the buffer layer. These islands enable hole injection into the buffer layer, and thus, they decrease metastability without increasing buffer absorption. Figure 5a compares quantum efficiency (QE) from devices with a standard CdS buffer, one with a standard $\mathrm{Zn}(\mathrm{O}, \mathrm{S})$ buffer, and a third with a $\mathrm{Zn}(\mathrm{O}, \mathrm{S})$ buffer with CdS islands. The addition of the CdS islands does not appreciably decrease the blue response of the device. Figures $5 b$ and $5 c$ compare the change in $V_{O C}$ of these three devices as a function of time, over two different timescales. From the small change in $V_{o c}$ of the devices with $\mathrm{Zn}(\mathrm{O}, \mathrm{S})+\mathrm{CdS}$ islands (red traces), it can be seen that the presence of the CdS islands dramatically decreases metastability.

During the course of this project, we have made excellent progress in understanding CIGS device metastability. We have challenged the long-held theory that metastability is solely a function of defects in the CIGS absorber by proving that the metastability seen in commercial products is likely to be caused by the buffer layer. Our discovery has been supported by SCAPS device modeling and confirmed by experimental devices. A dramatic reduction of metastability in CIGS solar cells was realized by introducing $\mathrm{CdS}$ islands adjacent to $\mathrm{Zn}(\mathrm{O}, \mathrm{S})$ buffer layers.
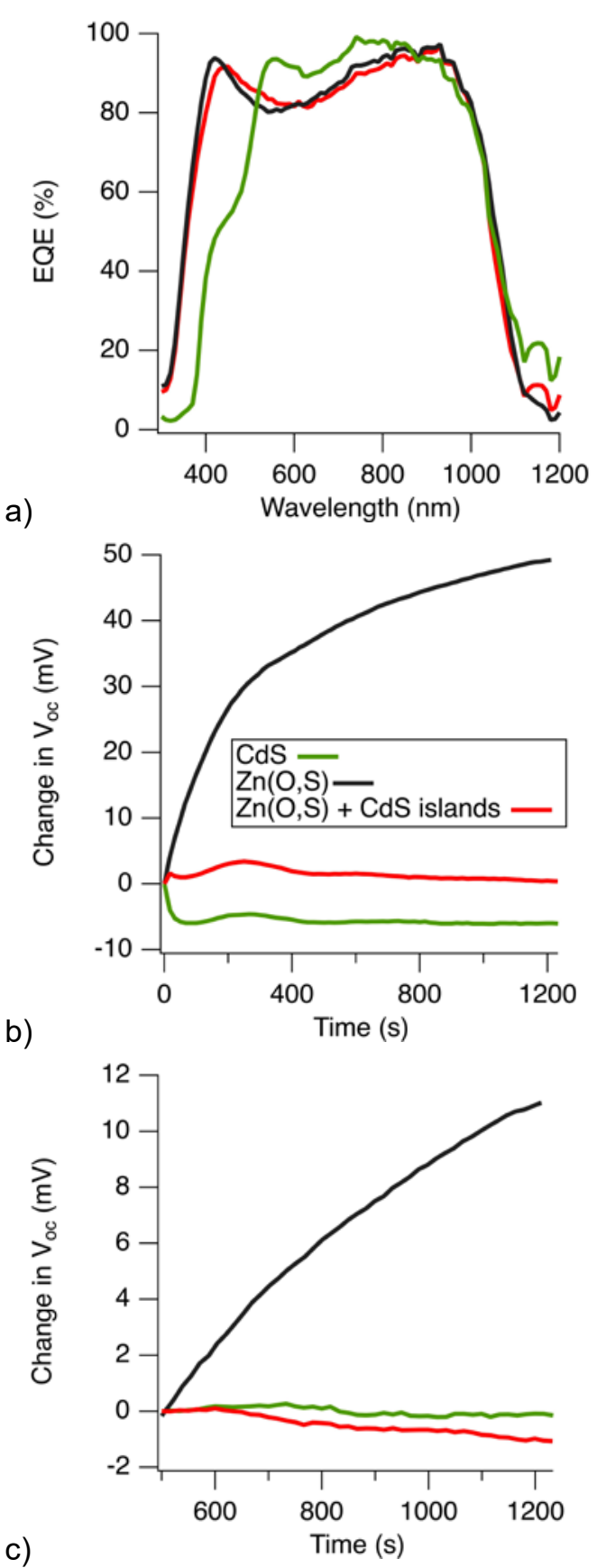

Figure 5: Comparison of devices with three different buffer designs, in terms of a) QE, b) voltage increase over 20 minutes of light soak, and c) voltage increase 500-1200 seconds after initial exposure. 


\section{Task 2 Reverse-Bias Shading - Summary}

Partial shading can degrade module performance by forcing reverse current through the shaded cells. Our original hypothesis was that fabricating devices with a thinner CIGS layer would confine the electric field and allow the reverse current to flow at lower voltages, thus reducing the power dissipated and the likelihood of damage. We modeled thin devices to determine how to attain the highest efficiency and were able to fabricate devices with $0.49-\mu \mathrm{m}$ CIGS that had $15.2 \%$ efficiency. However, reverse-bias behavior was not significantly improved. Taking a cue from previous reverse biasing of $Z n(O, S)$ devices, we improved reverse-bias behavior in CdS devices by removing the i-ZnO layer from the device stack. Both the $\mathrm{CdS}$ devices without $\mathrm{i}-\mathrm{ZnO}$ and the $\mathrm{Zn}(\mathrm{O}, \mathrm{S})$ devices were able to survive twice the maximum power-point current in reverse without damage.

\section{Background}

Partial shading can degrade module performance by forcing reverse current through the shaded cells. Silverman et al. found that modules lost $4 \%-7 \%$ of their maximum power due to shunting caused by partial shade [21]. The damage is observed as visible "worm trails" in Figure 6 . We have been able to reproduce this damage in small-area cells by subjecting them to reverse bias in the dark.

\section{Thin CIGS Devices - Modeling and Performance}

It is difficult to evaluate changes to current and voltage separately by device fabrication trials, especially

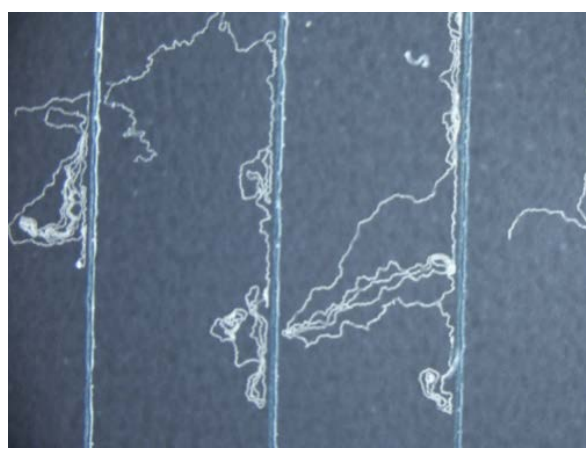

Figure 6: Image of visible damage ("worm trails") to a CIGS module caused by partial shading. when determining how $\mathrm{Ga}$ content should change through the device thickness. Therefore, we used device modeling to investigate the effect of $\mathrm{Ga}$ content in ultra-thin CIGS devices. We first wanted to determine the optimum "height" of the $\mathrm{Ga} /(\mathrm{Ga}+\mathrm{In})$ $(\mathrm{Ga} / \mathrm{III})$ at the rear of the film near the CIGS/Mo interface, which can act as an electron reflector at the back of the device. In Figure $7 \mathrm{a}$, at a thickness of $2 \mu \mathrm{m}$, the efficiency can be greater than $20 \%$ for rear $\mathrm{Ga} / \mathrm{III}$ ratio of 0.3 and higher, with the best efficiency coming from rear $\mathrm{Ga} / \mathrm{III}=0.6$. For thinner $\mathrm{CIGS}$ films, the highest efficiencies also occur at rear $\mathrm{Ga} / \mathrm{III}=0.6$, but the efficiency numbers are lower. This modeling indicates that it is
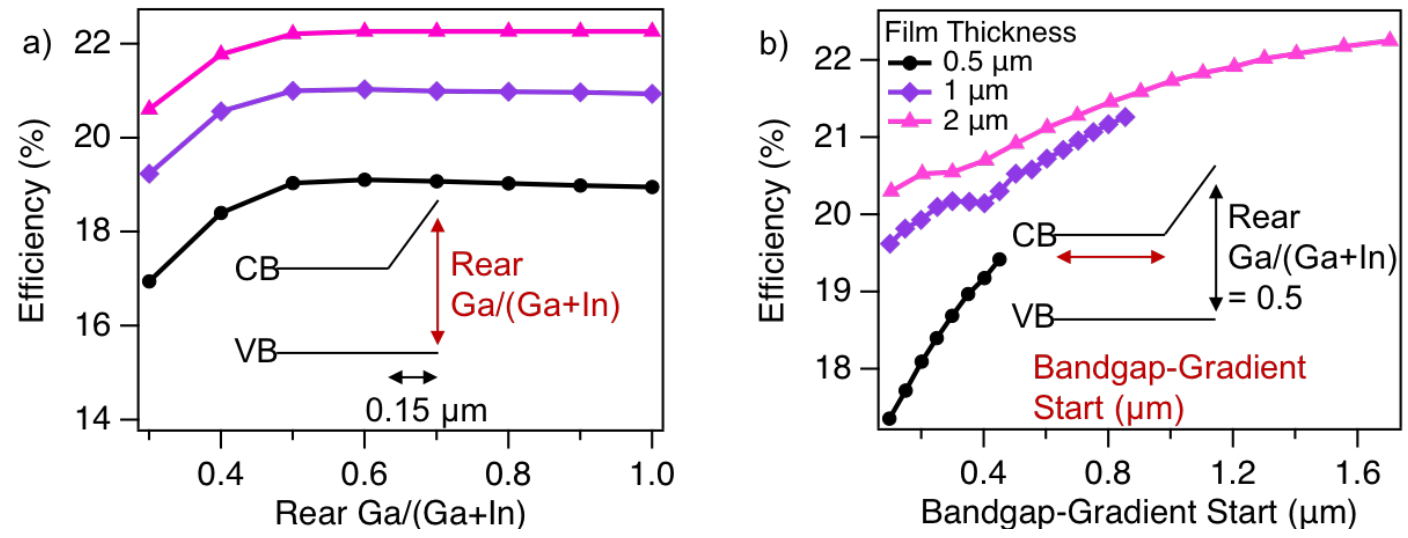

Figure 7: (a) Efficiency versus rear $\mathrm{Ga} /(\mathrm{Ga}+\mathrm{In})$ and (b) efficiency versus bandgap-gradient start for three different film thicknesses. Insets show, by red arrows, the portion of the bandgap that is changing. 
possible to achieve $19 \%$ efficiency for $0.5-\mu \mathrm{m}$ devices. The device model also leads to the conclusion that the rear $\mathrm{Ga} / \mathrm{III}$ of the $0.5-\mu \mathrm{m} \mathrm{CIGS}$ films should be at least 0.5 to 0.6 . This is a difference in $\mathrm{Ga} / \mathrm{III}$ of at least 0.3 over the rest of the film. In general, the efficiency is also increased when the start of the bandgap-gradient is farther from the film surface (Figure 7b). The dependency of efficiency on bandgap-gradient start depth is particularly strong for the ultra-thin CIGS films with a thickness of $0.5 \mu \mathrm{m}$. Optimization would result in a very thin layer of high-Ga CIGS. It also means that the rear Ga gradient should be as steep as possible to increase the device efficiency. More than $19 \%$ efficiency could be achieved if the bandgap-gradient start depth is greater than 0.35 , or stated alternatively, if the high-Ga region is less than $0.15 \mu \mathrm{m}$ thick.

To aid in fabricating the Ga gradients that were modeled, we developed a prediction tool for Ga gradients. As shown above, the gradients are important to device performance, and they vary as a function of growth recipe. Predicting Ga profiles using classic diffusion equations is not possible for a couple of reasons. First, In and Ga atoms occupy the same lattice sites - thus, they diffuse interdependently. Second, there is not yet a detailed experimental knowledge of the chemical potential as a function of composition that describes this interaction. We showed how diffusion equations can be modified to account for site sharing between In and $\mathrm{Ga}$ atoms [37]. The analysis was implemented in an Excel spreadsheet, and outputs predicted $\mathrm{Cu}$, In, and Ga profiles for entered deposition recipes. A single set of diffusion coefficients and activation energies was chosen such that simulated elemental profiles track with published data and our own experiments.

Device modeling and diffusion modeling guided our attempt to achieve high-efficiency ultra-thin CIGS solar cells. The best devices from this study are plotted in Figure 8 , along with best results from some other studies [1-6]. The devices most similar to ours in performance are from Kim et al., with efficiency of $13.7 \%$ at $0.5 \mu \mathrm{m}$ [6]. Vermang et al. used rear passivation to attain devices of $13.5 \%$ efficiency at $0.4 \mu \mathrm{m}$ [3]. In our experiments, we did not use additional passivation like Vermang's, light-management schemes as reviewed by Schmid [38], or the increasingly popular postdeposition alkali treatments. This

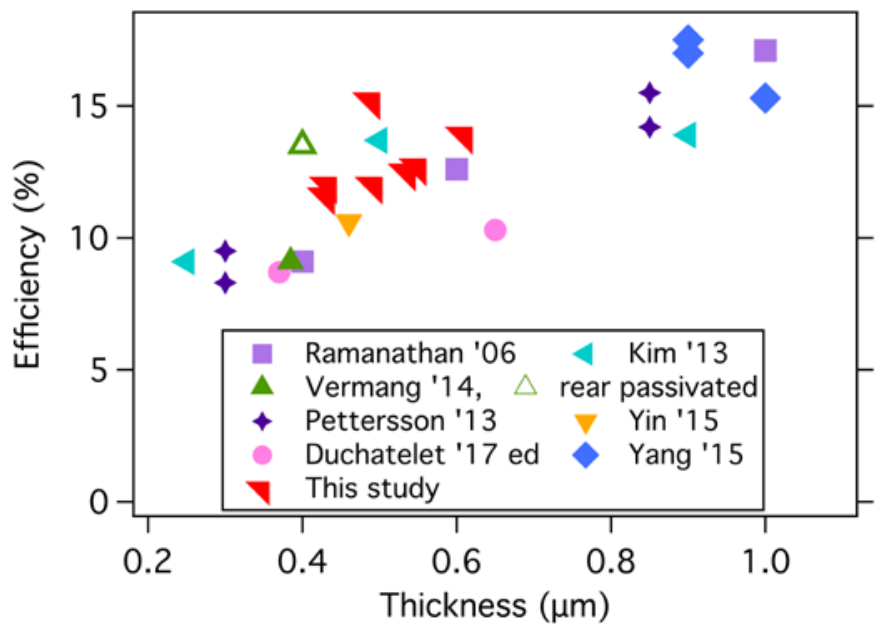

Figure 8: Efficiency versus thickness for several previous studies [1-6] on ultra-thin CIGS. The best efficiencies from this study are shown by red triangles pointing toward the upper right.

indicates that even higher device performance is possible. We were able to increase the efficiency of our ultra-thin CIGS for thicknesses between 0.43 and $0.65 \mu \mathrm{m}$. Our best cell was measured at $15.15 \%$ efficiency and had a CIGS thickness of $0.49 \mu \mathrm{m}$. It had the highest voltage of our samples at $0.733 \mathrm{~V}$, plus good current at $26.4 \mathrm{~mA} / \mathrm{cm}^{2}$ and fill factor of $78.2 \%$. The official JV measurement was taken by NREL's Solar Cell/Module Performance Group. Full details can be found in reference [39]. 
Reverse-Bias Behavior

We reverse-biased devices with a variety of $\mathrm{Cu}(\mathrm{In}, \mathrm{Ga}) \mathrm{Se}_{2}$ absorber thicknesses from $0.4 \mu \mathrm{m}$ to $2.5 \mu \mathrm{m}$, with the expectation that larger reverse current would be allowed to flow at lower voltages. Our initial experiments showed promise. However, as the efficiency of thin devices was improved, the reverse current allowed at a given voltage decreased. To display this phenomenon, we tried several different metrics. Originally, we calculated reverse breakdown voltage after the method of Puttnins et al. [40], but our CdS devices did not always show a turn-on voltage in reverse before becoming damaged. We also looked at voltages to reach a given current density, such as

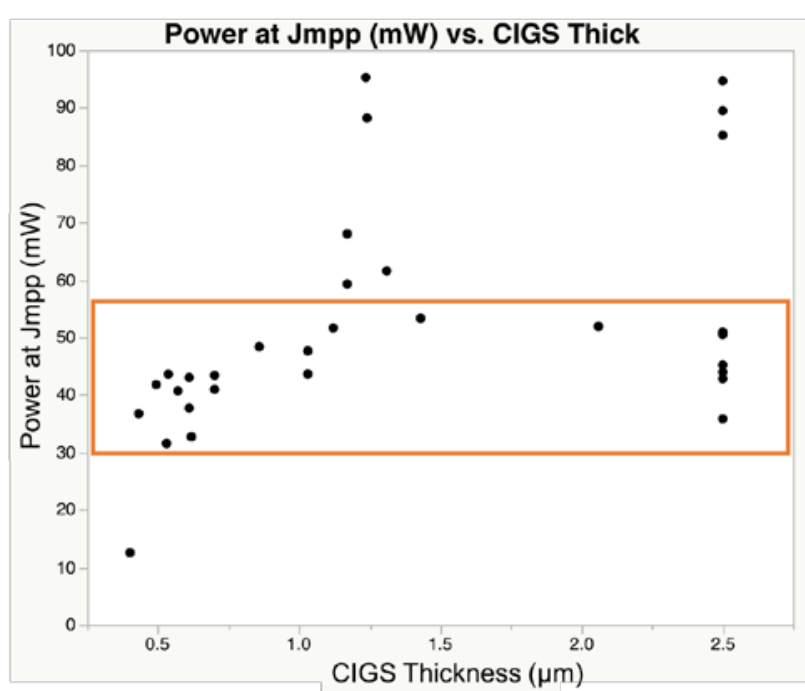

Figure 9: Power dissipated at $J_{m p p}$ in reverse bias versus CIGS film thickness. maximum power-point current $\left(\mathrm{J}_{\mathrm{mpp}}\right)$ or $-30 \mathrm{~mA} / \mathrm{cm}^{2}$. The best metric was to calculate the power dissipated $\left(P=I^{*} V\right)$ for those devices that reached the $J_{m p p}$ in reverse. This makes sense as a comparison between devices because we can easily understand that more power dissipated will indicate device damage. The power in $\mathrm{mW}$ versus CIGS absorber thickness is shown in Figure 9. The orange box is to indicate that most of the devices are within that power range regardless of thickness. We should note that not all devices were able to allow $\mathrm{Jmpp}_{\mathrm{m}}$ in reverse without damage and the devices that failed are not on the graph.

\section{Processing Changes}

We did discover one processing change that improved reverse-bias behavior. Lee et al. showed that $\mathrm{Zn}(\mathrm{O}, \mathrm{S})$ buffers were able to allow more current flow in reverse at lower voltages [22]. We saw similar results in our $\mathrm{Zn}(\mathrm{O}, \mathrm{S})$ devices and wanted to find out if the $\mathrm{i}-\mathrm{ZnO}$ and $\mathrm{AZO}$ layers affected the device's ability to reach $\mathrm{J}_{\mathrm{mpp}}$ in reverse bias. Comparisons of the device stacks of $\mathrm{Zn}(\mathrm{O}, \mathrm{S})$ and $\mathrm{CdS}$ devices are shown in Figure 10. We did several iterations of CdS devices with thinner i-ZnO layers, with AZO only (no i$\mathrm{ZnO}$ layer), and with thicker AZO layer. A comparison of the power dissipated at $J_{\mathrm{mpp}}$ in reverse for CdS with $A Z O$ only, standard CdS with bi-layer $\mathrm{ZnO}$, and $\mathrm{Zn}(\mathrm{O}, \mathrm{S})$ devices is shown in Figure 11a. The orange box is the same power range as in Figure 9, indicating the common range of power dissipated at $J_{\mathrm{mpp}}$ for standard CdS devices. This set does not include devices that were damaged before reaching $\mathrm{J}_{\mathrm{mpp}}$ in reverse, which was about $50 \%$ of the CdS devices. We are pleased to report that devices without an $\mathrm{i}-\mathrm{ZnO}$ layer-the $\mathrm{CdS}$ with $\mathrm{AZO}$ only and the $\mathrm{Zn}(\mathrm{O}, \mathrm{S})$ devices - were consistently able to reach $J_{m p p}$ (and even $2 \times J_{m p p}$, Figure 11b) in reverse bias without damage.

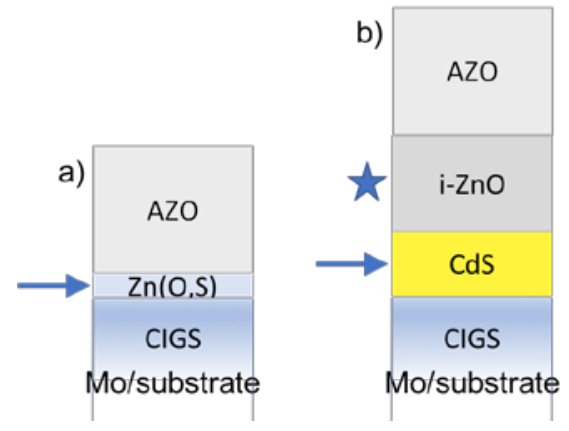

Figure 10: Diagrams of (a) $\mathrm{Zn}(\mathrm{O}, \mathrm{S})$ and (b) CdS device stacks. The buffer layers are indicated with arrows. 
The reverse-bias and partial-shading task led to some important conclusions. Device models confirmed that $19 \%$ devices are possible with $0.5-\mu \mathrm{m}$ CIGS layers. We were able to fabricate $15.2 \%$-efficiency devices with thin absorber layers, significantly improving upon the previous efficiency of ultra-thin CIGS devices. With these best-in-class devices, we also found that the reverse-bias characteristics do not depend on absorber thickness. We discovered that the best way to dissipate less power in reverse bias was to eliminate the intrinsic $\mathrm{ZnO}$ layer that is often used in CIGS devices. Lower power dissipation led to devices that allowed $2 \times J_{\mathrm{mpp}}$ in reverse current without damage.
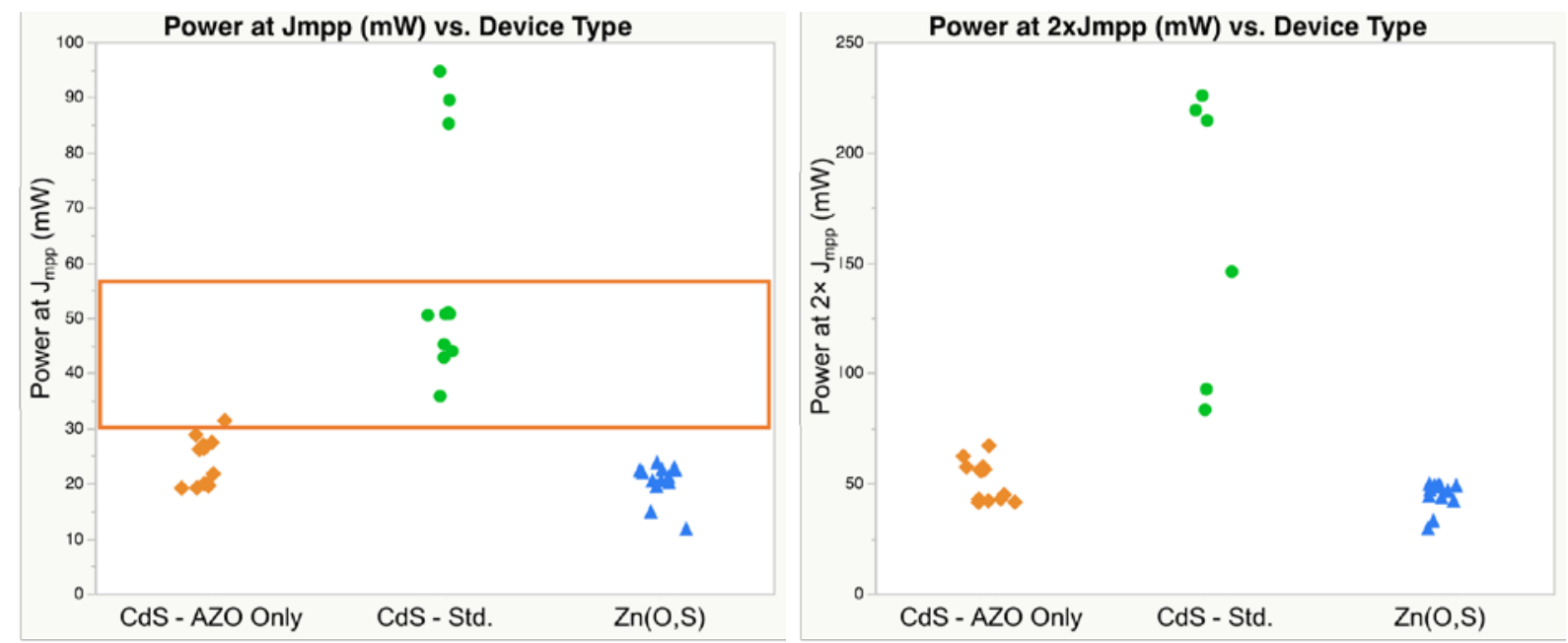

Figure 11: (a) Power at $J_{\text {mpp }}$ versus device type and (b) power at $2 x J_{\text {mpp }}$ versus device type. The orange box in (a) indicates the common range of power dissipated at $J_{m p p}$ for standard CdS devices.

\section{Task 3 Potential-Induced Degradation - Background}

Studying potential-induced degradation (PID) can add value to photovoltaic (PV) modules by helping to accurately predict power output and mitigate degradation. CIGS absorbers are known to benefit from alkali-metal dopants, which can diffuse out from soda-lime glass (SLG) substrates to enhance carrier concentration and reduce recombination [41]. On the other hand, transport of $\mathrm{Na}^{+}$from SLG into the semiconductors is the cause of PID in $\mathrm{Si}$, CdTe, and CIGS modules [28]. Therefore, alkali metals can both benefit and deteriorate PV performance, depending on their particular distribution and bonding. Careful study of these characteristics is needed to optimize the initial efficiency and degradation of CIGS modules.

\section{Samples}

To study CIGS PID, a method for packaging seven small-area solar cells $\left(0.42 \mathrm{~cm}^{2}\right.$ each) into module-like encapsulated samples was developed [42]. Standard CIGS device stacks were grown on various substrates: SLG, two borosilicate glasses (BSG), and SLG with an $\mathrm{Al}_{2} \mathrm{O}_{3}$ diffusion barrier. A KF post-deposition treatment (PDT) was additionally performed on SLG substrates. KF PDTs are known to enhance initial efficiency [41], but studies have connected alkali metals with degradation in damp heat [41], so more work is needed to understand how KF PDTs affect power produced over the lifetime of the PV module. The present study also employed K-rich borosilicate glass substrates instead of Na-rich SLG as a means to achieve comparable initial performance with reduced PID. 
Multiple BSGs were explored at first, and Schott D263 BSG was the best of all investigated because of its high $\mathrm{K}$ content and thermal expansion coefficient of $7 \times 10^{-6} \mathrm{~K}$ -1 , which was well-matched to that of CIGS $\left(\sim 7-9 \times 10^{-6} \mathrm{~K}^{-1}\right)$. The SLG with an $\mathrm{Al}_{2} \mathrm{O}_{3}$ diffusion barrier was chosen to be similar to substrates used in industry.

Diffusion $\left(85^{\circ} \mathrm{C}\right.$; no bias)

Before PID studies were performed, thermal anneals were examined as control samples-these samples endured long-term exposure to $85^{\circ} \mathrm{C}$ without bias. Independent of the thermal anneals' duration, samples of every type exhibited a decrease in carrier concentration by $2 x$ to $3 x$ (Figure 12). As expected, this coincided with small Voc and efficiency reductions. These changes may be attributable to diffusion, possibly through a redistribution of alkali metals. $\mathrm{Na}$ is smaller than $\mathrm{K}$, so it should have a higher diffusivity at $85^{\circ} \mathrm{C}$. Na's smaller atomic radius should also make its grain-interior defect formation energies more favorable than $\mathrm{K}$, likely making it a more active dopant [41]. For these reasons, the redistribution of $\mathrm{Na}$ may dominate the observed carrier concentration and efficiency losses after thermal diffusion.

\section{Drift and Diffusion $\left(-1000 \mathrm{~V}\right.$ and $\left.85^{\circ} \mathrm{C}\right)$}

Previous studies of CIGS PID have shown that it is crucial to separate moisture and potential effects [28], so the present study employed encapsulation. Bias can be applied across the substrate glass or the cover glass, and both have been shown to cause PID [28]. In this study, four configurations were initially tested on SLG substrates: positive or negative 1000 $V$, in each case applied either across the substrate or across the cover glass. Bias across the cover glass with both polarities had little or no effect after $100 \mathrm{~h}$ of stress. Applying positive bias to the cells with the back of the substrate grounded, which establishes an

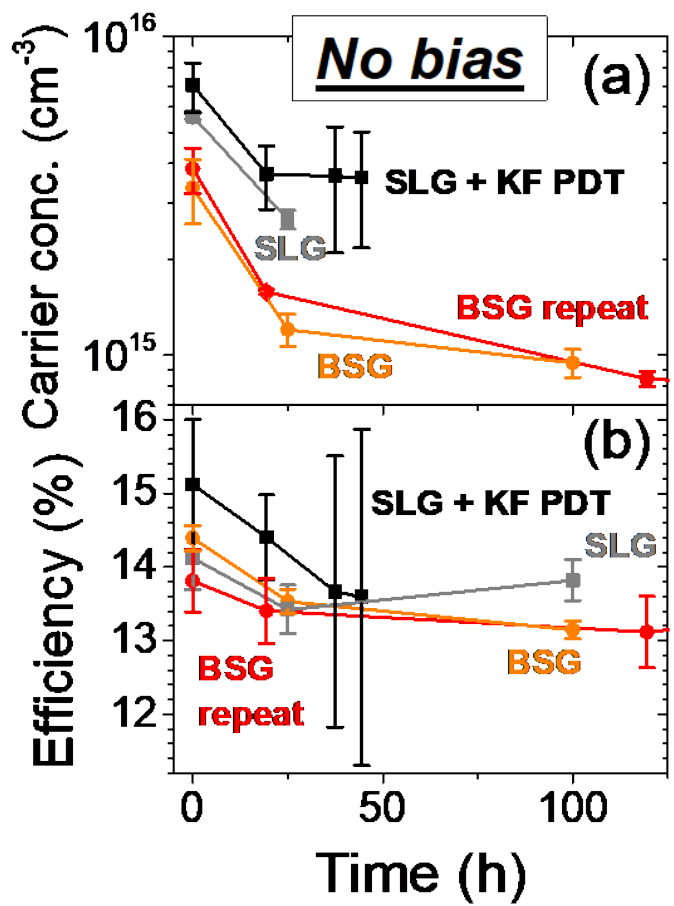

Figure 12: (a) Carrier concentration and (b) efficiency means and standard deviations (error bars) as a function of time at $85^{\circ} \mathrm{C}$ and $10 \%$ relative humidity (no bias) for SLG (gray squares), SLG + KF PDT (black squares), $B S G$ (orange circles), and repeated $B S G$ (red circles) substrates. electric field from the device toward the back (and should drive $\mathrm{Na}^{+}$the same direction), did not cause PID in $100 \mathrm{~h}$, and may have even improved performance. Applying negative bias to the cells to establish an electric field from the back toward the device (driving $\mathrm{Na}^{+}$ from the substrate into the device) caused catastrophic PID. In some cases, the PID (efficiency and carrier concentration losses) could be recovered by reversing the voltage polarity, in agreement with former reports [28]. However, the drops in efficiency and carrier concentration associated with thermal diffusion (Figure 13) were not restored by the polarity switch. The most damaging configuration $(-1000 \mathrm{~V}$ on the substrate) was carried on for the rest of the experiments. 
Initial PV performance of the BSG devices was almost as good as the standard SLG devices (Figure 12) because high levels of $K$ diffused out from the BSG into the growing absorbers (Figure 13). This caused the absorber K secondary-ion mass spectrometry (SIMS) signal on BSG substrates to be similar to the absorber Na SIMS signal on SLG substrates. This relatively high apparent concentration of $\mathrm{K}$ established majoritycarrier hole concentrations approaching those established by Na on SLG substrates (Figure 12). In this way, $K$ can achieve similar effects to $\mathrm{Na}$ with respect to absorbers' initial PV performance. The SLG PID absorber had increased $\mathrm{Na}$ after $25 \mathrm{~h}$ of PID, and likewise, the BSG PID sample had more $K$ in the absorber than the BSG control. However, the gain in $B S G$ absorber $K$ was less pronounced than the Na gain on SLG due to the BSG's 35x lower leakage current. The present results suggest that PID occurred through harm to the p-n junction itself (SIMS not shown [43])as opposed to $\mathrm{ZnO}$ corrosion, which has been observed in previous CIGS PID studies [28]. $\mathrm{ZnO}$ corrosion is much faster in the presence of moisture, highlighting the importance of encapsulation for PID testing.

After $25 \mathrm{~h}$ of stress, the SLG and KF PDT (not shown) samples exhibited catastrophic $\mathrm{PID}$ to $0 \%$ efficiency, while the $\mathrm{BSG}$ and $\mathrm{SLG} / \mathrm{Al}_{2} \mathrm{O}_{3}$ substrates suffered much less degradation (Figure 14). Much longer stressing durations were carried on, and slow PID was observed out to $700 \mathrm{~h}$. Figure 14 summarizes the contrast in stability among the samples: on average, the SLG, $\mathrm{SLG} / \mathrm{Al}_{2} \mathrm{O}_{3}$, and $\mathrm{BSG}$ solar cells degraded to $<50 \%$ of their initial efficiency within 6,30 , and $500 \mathrm{~h}$, respectively.

PID was also compared on the basis of Coulombs transferred. After physically driving equal amounts of cations into the devices, the SLG, BSG, and $S L G / \mathrm{Al}_{2} \mathrm{O}_{3}$ showed different trends. BSG substrates had the least PID with respect to time, but the $\mathrm{SLG} / \mathrm{Al}_{2} \mathrm{O}_{3}$ substrates had the least PID with respect to Coulombs transferred. The $\mathrm{Al}_{2} \mathrm{O}_{3}$ diffusion barrier did not alter the leakage current of SLG substrates, and the Na driven through the $\mathrm{Al}_{2} \mathrm{O}_{3}$ diffusion barrier initially improved carrier concentration and efficiency. After $15 \mathrm{~h}$ (or $0.05 \mathrm{C}$ ), too much $\mathrm{Na}$ had accumulated and PID occurred. The $\mathrm{Al}_{2} \mathrm{O}_{3}$ samples may have different slopes than SLG in Figure 14 and Figure 15 because they received more time at $85^{\circ} \mathrm{C}$, light soaking, and bias sweeping, all of which can reverse PID [25]. The BSG samples also had much longer durations at $85^{\circ} \mathrm{C}$, so roughly $24 \mathrm{x}$ more diffusion should 


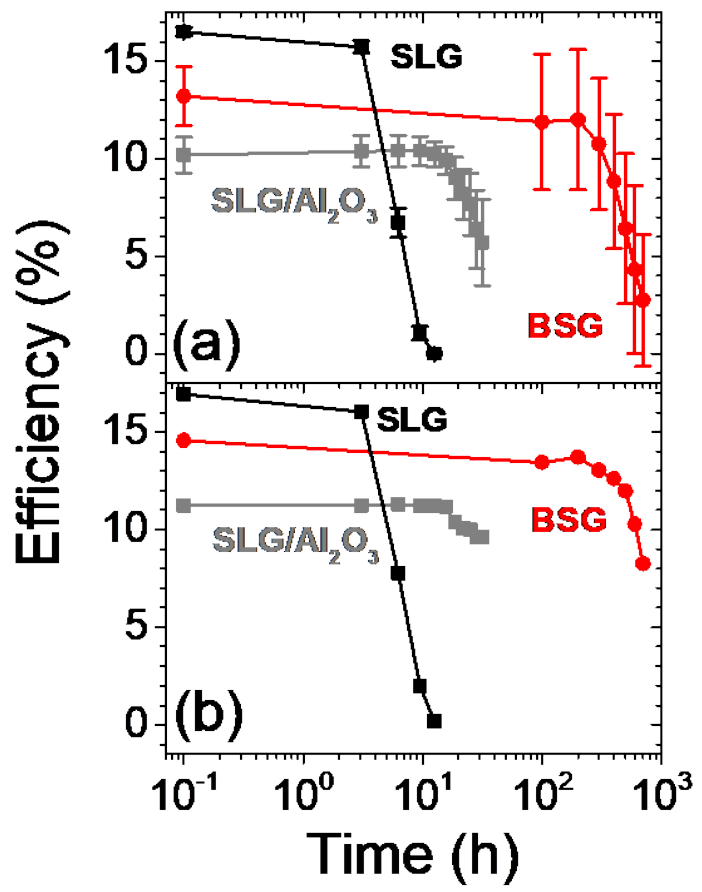

Figure 15: (a) Efficiency means and standard deviations (error bars) and (b) champions as a function of time at $-1000 \mathrm{~V}$ bias, $85^{\circ} \mathrm{C}$, and $10 \%$ relative humidity for SLG (black squares), $\mathrm{SLG} / \mathrm{Al}_{2} \mathrm{O}_{3}$ (gray squares), and BSG (red circles).

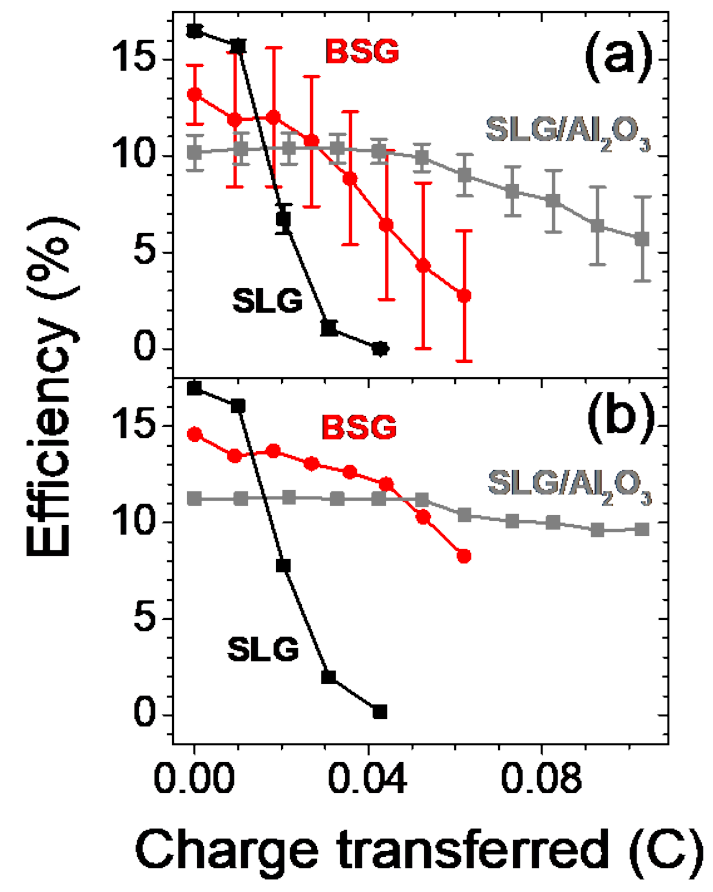

Figure 14: (a) Efficiency means and standard deviations (error bars) and (b) champions as a function of cumulative charge transferred at $1000 \mathrm{~V}$ bias, $85^{\circ} \mathrm{C}$, and $10 \%$ relative humidity for $\mathrm{SLG}$ (black squares), $\mathrm{SLG} / \mathrm{Al}_{2} \mathrm{O}_{3}$ (gray squares), and BSG (red circles) substrates.

have occurred relative to SLG. Diffusion could be reducing the $\mathrm{K}^{+}$accumulation in the junction that high bias causes, which could also explain the recovery after PID that has been reported to occur even at room temperature [44]. The possibility of test-specific degradation in Figure 14 and Figure 15 must be checked in future work by approximating field conditions more closely (e.g., combining high-voltage stress with light soaking and device bias).

\section{Processing Changes}

This study examined the effect of switching from SLG to BSG substrates on PID of CIGS. The high $\mathrm{K}$ levels in BSG led to increased $\mathrm{K}$ in the absorber layer, which led to initial PV performance similar to devices on standard SLG substrates. High-voltage stressing led to catastrophic PID of solar cells on SLG substrates after just $6 \mathrm{~h}$. In contrast, solar cells on BSG substrates required $500 \mathrm{~h}$ of stress for catastrophic PID. The SLG PID was associated with increased $\mathrm{Na}$ in the absorber, especially near the buffer interface. The less-conductive BSG had reduced leakage current, which diminished PID. Unencapsulated experiments have observed $\mathrm{ZnO}$ corrosion-based PID, but encapsulated PID is due to physical accumulation of ions in the junction. These cations initiate PID by compensating to reduce charge-carrier concentration, built-in voltage, $V_{o c}$, and efficiency, although catastrophic PID could also relate to shunting or interface recombination. In contrast to the PID-diminishing BSG substrates, SLG with $\mathrm{Al}_{2} \mathrm{O}_{3}$ diffusion barriers reduced PID without altering leakage current. Further experiments are needed on $\mathrm{SLG}$ with $\mathrm{Al}_{2} \mathrm{O}_{3}$ diffusion barriers with added alkali to increase the device efficiencies. 
These laboratory studies emulated field PID using smaller sample areas and shorter timescales. PID of encapsulated CIGS was due to alkali-metal ion drift from the glass substrate, followed by catastrophic accumulation of alkali metal in the junction. These findings indicate that PID testing can be accelerated by using a basis of Coulombs transferred. Similar studies of CdTe modules in the Photovoltaic Quality Assurance Task Force (PVQAT) project have shown that Coulombs transferred in the chamber for a given power-loss level relate well to Coulombs transferred in the field. For this project, two methods for mitigating PID were identified: using less-conductive glass and using a diffusion barrier on the glass to limit initial absorber alkali-metal content. Our results show that less-conductive BSG substrates reduce the Coulomb transfer rate and offer a processing solution for dramatically reducing PID.

Conclusions: Most milestones in the project were met, although some took slightly longer to complete than others. In particular, fabricating an ultra-thin CIGS solar cell with efficiency of $15 \%$ was more difficult than expected. This caused the annual milestones 1.2.3 and 2.2.4 to be completed later in the project than planned. Reducing metastability by using a Cd partial-electrolyte before the $\mathrm{Zn}(\mathrm{O}, \mathrm{S})$ buffer layer was an unmet Quarterly Performance Indicator (QPI). We were able to do this once earlier in the project, but we were unable to replicate the results. The QPI dealing with reverse-biasing encapsulated NREL cells (3.2.1) also did not go as planned because NREL devices tended to break down at the grid lines unlike our partner cells, which did not have grids.

This project did demonstrate that investigating cell-level reliability is an effective way to solve module reliability problems. We were able to reduce metastability by adding CdS islands to our $\mathrm{Zn}(O, S)$ buffers. Reverse-bias damage was mitigated by removing the i$\mathrm{ZnO}$ layer from devices, when using either a $\mathrm{Zn}(\mathrm{O}, \mathrm{S})$ buffer or a CdS buffer. Potentialinduced degradation was also slowed by replacing the soda-lime back glass with a low$\mathrm{Na}$, high-K borosilicate glass. These changes could be implemented in modules to help solve the three main reliability problems in CIGS PV.

Budget and Schedule:

\begin{tabular}{|c|c|c|c|c|c|c|c|}
\hline Budget Categories per SF-424a & BP 1 & & BP 2 & & BP 3 & & Total \\
\hline k. Total Charges & 926,586 & $\$$ & $1,175,121$ & $\$$ & $1,218,293$ & $\$$ & $3,320,000$ \\
\hline DOE Share & 926,586 & $\$$ & $1,175,121$ & $\$$ & $1,218,293$ & \$ & $3,320,000$ \\
\hline Cost Share & & & & & & $\$$ & - \\
\hline Cost Share Percentage & $0.0 \%$ & & $0.0 \%$ & & $0.0 \%$ & & $0.0 \%$ \\
\hline
\end{tabular}

Path Forward: Open questions still exist in the field of cell-level reliability. We found that $\mathrm{CdS}$ islands reduce the metastability of CIGS devices with $\mathrm{Zn}(\mathrm{O}, \mathrm{S})$. However, we did not explore other materials that may be able to perform a similar function. Reducing the $\mathrm{Cd}$ in the device stack is always a priority, so there are research opportunities in finding materials that can inject holes into the $\mathrm{Zn}(\mathrm{O}, \mathrm{S})$ buffer layer, or alternative buffer layers that would provide stability without the use of $\mathrm{Cd}$. The definition of metastability used in this project was of reversible changes. Other degradation mechanisms, such as irreversible performance decreases caused by heat and light-soaking, could be studied in a similar fashion. Reverse-bias behavior in solar cells is not commonly explored, and the field could benefit from having a device module that attempts to describe it. This would allow predictions of reverse-bias behavior in modified device structures before the actual 
fabrication occurs. Another area for study in PID is whether or not a device with only $\mathrm{K}$ and no $\mathrm{Na}$ will degrade as quickly as the devices on soda-lime glass. In addition, the front-grounded PID stress configuration should be explored because it has also been identified as a cause of degradation in modules. Finally, the framework we have used for studying cell-level reliability and using it to solve module-level problems could be expanded to other solar cell technologies. This is by no means an exhaustive list, but there is certainly room for additional discoveries in the little-studied field of cell-level reliability.

Publications Resulting from This Work: Not all of the publications resulting from the project work were able to be referenced in the text. Those already referenced will appear again in the following references list. Some of the included references are collaborations between two SuNLaMP projects.

A. M. C. Alonso-Garcia, P. Hacke, S. Glynn, C. P. Muzzillo, and L. M. Mansfield, "Analysis of Potential-Induced Degradation in Soda-Lime Glass and BorosilicateGlass $\mathrm{Cu}(\mathrm{In}, \mathrm{Ga}) \mathrm{Se}_{2}$ Samples," IEEE Journal of Photovoltaics, 2018. Submitted.

B. M. A. Contreras, P. Hacke, and I. Repins, "Development of $\mathrm{Cu}(\mathrm{In}, \mathrm{Ga}) \mathrm{Se}_{2}$ Test Coupons for Potential Induced Degradation Studies," Paper in 2016 IEEE 43rd Photovoltaic Specialists Conference (PVSC), Portland, OR, 5-10 June 2016, pp. 0857-0862.

C. S. Glynn, I. Repins, J. Burst, C. Beall, K. Bowers, and L. Mansfield, "Selective Excitation of Window and Buffer Layers in Chalcopyrite Devices and Modules," Thin Solid Films, Vol. 655, pp. 70-76, 2018.

D. S. P. Harvey, H. Guthrey, C. P. Muzzillo, L. Mansfield, G. Teeter, P. Hacke, S. Johnston, and M. Al-Jassim, "Investigating PID Shunting in Polycrystalline CIGS Devices via Multi-Scale, Multi-Technique Characterization," IEEE Journal of Photovoltaics, 2018. Submitted.

E. S. Johnston, E. Palmiotti, A. Gerber, L. Mansfield, T. J. Silverman, M. Al-Jassim, and A. Rockett, "Identifying Reverse-bias Breakdown Sites in Culn $\mathrm{Ga}_{(1-\mathrm{x}) \mathrm{Se}} \mathrm{Se}_{2}$ Photovoltaic Modules," Paper in IEEE PVSC, Washington, D.C., 2017.

F. S. Johnston, D. Sulas, E. Palmiotti, A. Gerber, H. Guthrey, L. Mansfield, T. J. Silverman, M. Al-Jassim, and A. Rockett, "Thin-Film Module Reverse-Bias Breakdown Sites Identified by Thermal Imaging," Paper in WCPEC-7/IEEE PVSC, Waikaloa, HI, June 10-15, 2018.

G. L. M. Mansfield, A. Kanevce, S. P. Harvey, K. Bowers, C. Beall, S. Glynn, and I. L. Repins, "Efficiency Increased to $15.2 \%$ for Ultra-Thin $\mathrm{Cu}(\mathrm{In}, \mathrm{Ga}) \mathrm{Se}_{2}$ Solar Cells," Progress in Photovoltaics: Research and Applications, Vol. 26, No. 11, pp. 949-954, 2018. https://doi.org/10.1002/pip.3033

H. H. R. Moutinho, B. To, C. S. Jiang, C. Xiao, C. Muzzillo, P. Hacke, J. Moseley, J. Tynan, N. G. Dhere, L. Mansfield, M. M. Al-Jassim, and S. Johnston, "Artifact-Free Coring Procedures for Removing Samples from Photovoltaic Modules for Microscopic Analysis," Paper in WCPEC-7/IEEE PVSC, Waikaloa, HI, June 10-15, 2018.

I. C. P. Muzzillo, S. Glynn, P. Hacke, H. R. Moutinho, M. R. Young, G. Teeter, I. L. Repins, and L. M. Mansfield, "Potential-Induced Degradation of $\mathrm{Cu}(\mathrm{In}, \mathrm{Ga}) \mathrm{Se}_{2}$ Solar Cells: Alkali Metal Drift and Diffusion Effects," IEEE Journal of Photovoltaics, Vol. 8, No. 5, pp. 1337-1342, 2018. http://dx.doi.org/10.1109/JPHOTOV.2018.2858549 
J. E. Palmiotti, S. Johnston, A. Gerber, H. Guthrey, A. Rockett, L. Mansfield, T. J. Silverman, and M. Al-Jassim, "Identification and Analysis of Partial Shading Breakdown Sites in CulnxGa(1-x)Se2 Modules," Solar Energy, Vol. 161, pp. 1-5, 2018. http://dx.doi.org/10.1016/j.solener.2017.12.019

K. I. L. Repins, S. Harvey, K. Bowers, S. Glynn, and L. M. Mansfield, "Predicting Ga and $\mathrm{Cu}$ Profiles in Co-evaporated $\mathrm{Cu}(\mathrm{In}, \mathrm{Ga}) \mathrm{Se}_{2}$ Using Modified Diffusion Equations and a Spreadsheet," MRS Advances, pp. 1-6, 2017. http://dx.doi.org/10.1557/adv.2017.350

L. T. J. Silverman, L. Mansfield, I. Repins, and S. Kurtz, "Damage in Monolithic Thin-Film Photovoltaic Modules Due to Partial Shade," IEEE Journal of Photovoltaics, Vol. 6, No. 5, pp. 1333-1338, 2016. http://dx.doi.org/10.1109/JPHOTOV.2016.2591330

Publications most closely related to previous work in CIGS or CZTS

a. J. Bailey, D. Poplavskyy, G. Zapalac, L. Mansfield, and W. Shafarman, "VoltageInduced Charge Redistribution in $\mathrm{Cu}(\mathrm{In}, \mathrm{Ga}) \mathrm{Se}_{2}$ Devices Studied with High-Speed Capacitance-Voltage Profiling," IEEE Journal of Photovoltaics, 2018. Accepted with minor revisions.

b. M. Bär, I. Repins, L. Weinhardt, J. H. Alsmeier, S. Pookpanratana, M. Blum, W. Yang, C. Heske, R. G. Wilks, and R. Noufi, "Zn-Se-Cd-S Interlayer Formation at the $\mathrm{CdS} / \mathrm{Cu}_{2} \mathrm{ZnSnSe} 4$ Thin-Film Solar Cell Interface," ACS Energy Letters, Vol. 2, No. 7 , pp. 1632-1640, 2017. http://dx.doi.org/10.1021/acsenergylett.7b00140

c. R. L. Garris, S. Johnston, J. V. Li, H. L. Guthrey, K. Ramanathan, and L. M. Mansfield, "Electrical Characterization and Comparison of CIGS Solar Cells Made with Different Structures and Fabrication Techniques," Solar Energy Materials and Solar Cells, Vol. 174, pp. 77-83, 2018. https://doi.org/10.1016/j.solmat.2017.08.027

d. R. L. Garris, L. M. Mansfield, B. Egaas, and K. Ramanathan, "Low-Cd CIGS Solar Cells Made with a Hybrid CdS/Zn(O,S) Buffer Layer," IEEE Journal of Photovoltaics, Vol. 7, No. 1, pp. 281-285, 2017. http://dx.doi.org/10.1109/JPHOTOV.2016.2617041

e. M. D. Heinemann, M. F. A. M. van Hest, M. Contreras, J. D. Perkins, A. Zakutayev, C. A. Kaufmann, T. Unold, D. S. Ginley, and J. J. Berry, "Amorphous Oxides as Electron Transport Layers in $\mathrm{Cu}(\mathrm{In}, \mathrm{Ga}) \mathrm{Se}_{2}$ Superstrate Devices," Physica Status Solidi (A) Applications and Materials Science, Vol. 214, No. 5, 2017. 10.1002/pssa.201600870

f. H. Hempel, R. Eichberger, I. Repins, and T. Unold, "The Effect of Cu-Zn Disorder on Charge Carrier Mobility and Life Time in $\mathrm{Cu}_{2} \mathrm{ZnSnSe} 4$," Submitted to Thin Solid Films, 2018.

g. H. Hempel, A. Redinger, I. Repins, C. Moisan, G. Larramona, G. Dennler, M. Handwerg, S. F. Fischer, R. Eichberger, and T. Unold, "Intragrain Charge Transport in Kesterite Thin Films-Limits Arising from Carrier Localization," Journal of Applied Physics, Vol. 120, No. 17, pp. 175302, 2016. http://dx.doi.org/10.1063/1.4965868

h. S. A. Jensen, S. Glynn, A. Kanevce, P. Dippo, J. V. Li, D. H. Levi and D. Kuciauskas, "Beneficial Effect of Post-Deposition Treatment in High-Efficiency $\mathrm{Cu}(\mathrm{In}, \mathrm{Ga}) \mathrm{Se}_{2}$ Solar Cells through Reduced Potential Fluctuations," Journal of Applied Physics, Vol. 120, No. 6, 2016. http://dx.doi.org/10.1063/1.4960344

i. S. A. Jensen, A. Kanevce, L. M. Mansfield, S. Glynn, S. Lany, and D. Kuciauskas, "Optically Induced Metastability in Cu(In, Ga)Se2," Scientific Reports, Vol. 7, No. 1, pp. s41598-41017, 2017. http://dx.doi.org/10.1038/s41598-017-14344-6 
j. C. S. Jiang, L. M. Mansfield, S. Glynn, C. Xiao, R. Garris, S. Christensen, and M. M. Al-Jassim, "Effect of Window-Layer Materials on $p-n$ Junction Location in $\mathrm{Cu}(\mathrm{In}, \mathrm{Ga}) \mathrm{Se}_{2}$ Solar Cells," IEEE Journal of Photovoltaics, 2018. Accepted

k. L. M. Mansfield, B. To, R. C. Reedy, M. R. Young, K. Bowers, and K. Ramanathan, "Investigation of Sb-Containing Precursors for $\mathrm{Cu}(\mathrm{In}, \mathrm{Ga}) \mathrm{Se}_{2}$ Thin Films through Design of Experiments," Paper in 2016 IEEE 43rd Photovoltaic Specialists Conference (PVSC), 5-10 June 2016, pp. 1157-1162,

I. M. Mezher, L. M. Mansfield, K. Horsley, M. Blum, R. Wieting, L. Weinhardt, K. Ramanathan, and C. Heske, "KF Post-Deposition Treatment of Industrial $\mathrm{Cu}(\mathrm{In}$, $\mathrm{Ga})(\mathrm{S}, \mathrm{Se})_{2}$ Thin-Film Surfaces: Modifying the Chemical and Electronic Structure," Applied Physics Letters, Vol. 111, No. 7, pp. 071601, 2017. http://dx.doi.org/10.1063/1.4998445

m. C. P. Muzzillo, J. V. Li, L. M. Mansfield, K. Ramanathan, and T. J. Anderson, "Surface and Bulk Effects of $\mathrm{K}$ in Highly Efficient $\mathrm{Cu}_{1-\mathrm{x}} \mathrm{K}_{\mathrm{x}} \mathrm{InSe} 2$ Solar Cells," Solar Energy Materials and Solar Cells, Vol. 185, pp. 45-53, 2018. http://dx.doi.org/10.1016/j.solmat.2018.05.013

n. M. C. P., P. J. D., T. H. Ming, G. Wei and A. Tim, "Revealing the Beneficial Role of K in Grain Interiors, Grain Boundaries, and at the Buffer Interface for Highly Efficient CulnSe $\mathrm{S}_{2}$ Solar Cells," Progress in Photovoltaics: Research and Applications, Vol. 26, No. 10, pp. 825-834, 2018. http://dx.doi.org/doi:10.1002/pip.3022

o. S. Paul, R. Lopez, I. L. Repins, and J. V. Li, "Study of Charge Transport Properties in a $\mathrm{ZnO} / \mathrm{CdS} / \mathrm{Cu}(\mathrm{In}, \mathrm{Ga}) \mathrm{Se}_{2}$ Solar Cell via Admittance Spectroscopy," Journal of Vacuum Science and Technology B: Nanotechnology and Microelectronics, Vol. 36, No. 2, 2018. http://dx.doi.org/10.1116/1.5013046

p. I. Repins, L. Mansfield, A. Kanevce, S. A. Jensen, D. Kuciauskas, S. Glynn, T. Barnes, W. Metzger, J. Burst, C. S. Jiang, P. Dippo, S. Harvey, G. Teeter, C. Perkins, B. Egaas, A. Zakutayev, J. H. Alsmeier, T. Lusky, L. Korte, R. G. Wilks, M. Bar, Y. Yan, S. Lany, P. Zawadzki, J. S. Park, and S. Wei, "Wild Band Edges: The Role of Bandgap Grading and Band-Edge Fluctuations in High-Efficiency Chalcogenide Devices," Paper Vol. 2016-November, pp. 309-314.

q. L. T. Schelhas, K. H. Stone, S. P. Harvey, D. Zakhidov, A. Salleo, G. Teeter, I. L. Repins, and M. F. Toney, "Point Defects in $\mathrm{Cu}_{2} Z n \mathrm{ZnSe}_{4}$ (CZTSe): Resonant X-Ray Diffraction Study of the Low-Temperature Order/Disorder Transition," Physica Status Solidi (B) Basic Research, Vol. 254, No. 9, 2017. http://dx.doi.org/10.1002/pssb.201700156

r. K. H. Stone, S. T. Christensen, S. P. Harvey, G. Teeter, I. L. Repins, and M. F. Toney, "Quantifying Point Defects in $\mathrm{Cu}_{2} \mathrm{ZnSn}(\mathrm{S}, \mathrm{Se})_{4}$ Thin Films using Resonant X-Ray Diffraction," Applied Physics Letters, Vol. 109, No. 16, pp. 161901, 2016. http://dx.doi.org/10.1063/1.4964738

\section{References:}

1. G. Yin, V. Brackmann, V. Hoffmann, and M. Schmid, "Enhanced performance of ultrathin $\mathrm{Cu}(\mathrm{In}, \mathrm{Ga}) \mathrm{Se}_{2}$ solar cells deposited at low process temperature," Solar Energy Materials and Solar Cells, Vol. 132, pp. 142-147, 2015. http://dx.doi.org/10.1016/j.solmat.2014.08.045 
2. K. Ramanathan, R. Noufi, B. To, D. L. Young, R. Bhattacharya, M. A. Contreras, R. G. Dhere, and G. Teeter, "Processing and properties of sub-micron CIGS solar cells," Paper in IEEE WCPEC-4, Vol. 1, pp. 380-383,

3. B. Vermang, J. T. Wätjen, V. Fjällström, F. Rostvall, M. Edoff, R. Kotipalli, F. Henry, and D. Flandre, "Employing Si solar cell technology to increase efficiency of ultra-thin $\mathrm{Cu}(\mathrm{In}, \mathrm{Ga}) \mathrm{Se}_{2}$ solar cells," Progress in Photovoltaics: Research and Applications, Vol. 22, No. 10, pp. 1023-1029, 2014. https://doi.org/10.1002/pip.2527

4. S. Yang, J. Zhu, X. Zhang, X. Ma, H. Luo, L. Yin, and X. Xiao, "Bandgap optimization of submicron-thick $\mathrm{Cu}(\mathrm{In}, \mathrm{Ga}) \mathrm{Se}_{2}$ solar cells," Progress in Photovoltaics: Research and Applications, Vol. 23, No. 9, pp. 1157-1163, 2015. https://doi.org/10.1002/pip.2543

5. A. Duchatelet, E. Letty, S. Jaime-Ferrer, P. P. Grand, F. Mollica, and N. Naghavi, "The impact of reducing the thickness of electrodeposited stacked $\mathrm{Cu} / \mathrm{In} / \mathrm{Ga}$ layers on the performance of CIGS solar cells," Solar Energy Materials and Solar Cells, Vol. 162, pp. 114-119, 2017. https://doi.org/10.1016/i.solmat.2016.12.045

6. K. Kim, H. Park, W. K. Kim, G. M. Hanket, and W. N. Shafarman, "Effect of Reduced $\mathrm{Cu}(\mathrm{InGa})(\mathrm{SeS})_{2}$ Thickness Using Three-Step $\mathrm{H}_{2} \mathrm{Se} / \mathrm{Ar} / \mathrm{H}_{2} \mathrm{~S}$ Reaction of Cu-In-Ga Metal Precursor," IEEE Journal of Photovoltaics, Vol. 3, No. 1, pp. 446-450, 2013. https://doi.org/10.1109/JPHOTOV.2012.2219501

7. A. Ferguson, P. Dippo, D. Kuciauskas, R. Farshchi, J. Bailey, G. Zapalac, and D. Poplavskyy, "Optical Spectroscopic Probes of Degradation and Metastability in Polycrystalline (Ag, $\mathrm{Cu})(\mathrm{In}, \mathrm{Ga}) \mathrm{Se}_{2}$ Absorbers," Paper Presented at WCPEC-7, Waikoloa, Hawaii, June 10-15, 2018.

8. J. F. L. Salas, S. J. Heise, M. Richter, V. Gerliz, M. S. Hammer, J. Ohland, and I. Hammer-Riedel, "Simulation of metastable changes in time resolved photoluminescence of $\mathrm{Cu}(\mathrm{In}, \mathrm{Ga}) \mathrm{Se}_{2}$ thin film solar cells upon light soaking treatment," Thin Solid Films, Vol. 633, No. Supplement C, pp. 40-44, 2017. https://doi.org/10.1016/j.tsf.2016.08.035

9. S. A. Jensen, A. Kanevce, L. M. Mansfield, S. Glynn, S. Lany, and D. Kuciauskas, "Optically induced metastability in $\mathrm{Cu}(\mathrm{In}, \mathrm{Ga}) \mathrm{Se}_{2}$," Scientific Reports, Vol. 7, No. 1, pp. s41598-41017, 2017. http://dx.doi.org/10.1038/s41598-017-14344-6

10. S. J. Heise, V. Gerliz, M. S. Hammer, J. Ohland, J. Keller, and I. Hammer-Riedel, "Light-induced changes in the minority carrier diffusion length of $\mathrm{Cu}(\mathrm{In}, \mathrm{Ga}) \mathrm{Se}_{2}$ absorber material," Solar Energy Materials and Solar Cells, Vol. 163, pp. 270-276, 2017. http://dx.doi.org/10.1016/j.solmat.2017.01.045

11. S. Lany and A. Zunger, "Light- and bias-induced metastabilities in $\mathrm{Cu}(\mathrm{In}, \mathrm{Ga}) \mathrm{Se}_{2}$ based solar cells caused by the ( $\mathrm{V}_{\mathrm{Se}}-\mathrm{V}_{\mathrm{Cu}}$ ) vacancy complex," Journal of Applied Physics, Vol. 100, No. 11, 2006. http://dx.doi.org/10.1063/1.2388256

12.W.-H. Ho, C.-H. Hsu, T.-H. Yeh, Y.-H. Chang, S.-Y. Wei, T.-Y. Lin, and C.-H. Lai, "Room-Temperature Chemical Solution Treatment for Flexible $\mathrm{ZnS}(\mathrm{O}, \mathrm{OH}) / \mathrm{Cu}(\mathrm{In}, \mathrm{Ga}) \mathrm{Se}_{2}$ Solar Cell: Improvements in Interface Properties and Metastability," ACS Applied Materials \& Interfaces, Vol. 8, No. 10, pp. 6709-6717, 2016. 10.1021/acsami.5b11028

13. W.-J. Lee, H.-J. Yu, J.-H. Wi, D.-H. Cho, W. S. Han, J. Yoo, Y. Yi, J.-H. Song, and Y.D. Chung, "Behavior of Photocarriers in the Light-Induced Metastable State in the pn Heterojunction of a $\mathrm{Cu}(\mathrm{In}, \mathrm{Ga}) \mathrm{Se}_{2}$ Solar Cell with CBD-ZnS Buffer Layer," ACS 
Applied Materials \& Interfaces, Vol. 8, No. 34, pp. 22151-22158, 2016. http://dx.doi.org/10.1021/acsami.6b05005

14. T. H. Yeh, C. H. Hsu, W. H. Ho, S. Y. Wei, C. H. Cai, and C. H. Lai, "An ammonia-free chemical-bath-deposited $\mathrm{ZnS}(\mathrm{O}, \mathrm{OH})$ buffer layer for flexible $\mathrm{Cu}(\mathrm{In}, \mathrm{Ga}) \mathrm{Se}_{2}$ solar cell application: An eco-friendly approach to achieving improved stability," Green Chemistry, Vol. 18, No. 19, pp. 5212-5218, 2016. 10.1039/c6gc01293k

15. C. Hönes, J. Hackenberg, R. Keller, S. Zweigart, A. Fuchs, and S. Siebentritt, "A Novel Fast Process for $\mathrm{Zn}(\mathrm{O}, \mathrm{S})$ Buffer Layers, Doped with Al and B and Deposited on CIGSSe Solar Cells," IEEE Journal of Photovoltaics, Vol. 7, No. 3, pp. 864-869, 2017. 10.1109/JPHOTOV.2017.2669360

16. S. Ishizuka, J. Nishinaga, M. lioka, H. Higuchi, Y. Kamikawa, T. Koida, H. Shibata, and P. Fons, "Si-Doped $\mathrm{Cu}(\mathrm{In}, \mathrm{Ga}) \mathrm{Se}_{2}$ Photovoltaic Devices with Energy Conversion Efficiencies Exceeding 16.5\% without a Buffer Layer," Advanced Energy Materials, Vol. 8, No. 11, 2018. 10.1002/aenm.201702391

17.E. Palmiotti, S. Johnston, A. Gerber, H. Guthrey, A. Rockett, L. Mansfield, T. J. Silverman, and M. Al-Jassim, "Identification and analysis of partial shading breakdown sites in Culn $\mathrm{Ga}_{(1-\mathrm{x})} \mathrm{Se}_{2}$ modules," Solar Energy, Vol. 161, pp. 1-5, 2018. http://dx.doi.org/10.1016/i.solener.2017.12.019

18. S. Johnston, D. Sulas, E. Palmiotti, A. Gerber, H. Guthrey, L. Mansfield, T. J. Silverman, M. Al-Jassim, and A. Rockett, "Thin-film Module Reverse-Bias Breakdown Sites Identified by Thermal Imaging," Paper in WCPEC-7/IEEE PVSC, Waikaloa, $\mathrm{HI}$, June 10-15, 2018.

19. S. Johnston, E. Palmiotti, A. Gerber, L. Mansfield, T. J. Silverman, M. Al-Jassim, and A. Rockett, "Identifying Reverse-bias Breakdown Sites in Culn $\times \mathrm{Ga}_{(1-x)} \mathrm{Se}_{2}$ Photovoltaic Modules," Paper in IEEE PVSC, Washington, D.C.,

20.P. Szaniawski, P. Zabierowski, J. Olsson, U. Zimmermann, and M. Edoff, "Advancing the Understanding of Reverse Breakdown in $\mathrm{Cu}(\mathrm{In}, \mathrm{Ga}) \mathrm{Se}_{2}$ Solar Cells," IEEE Journal of Photovoltaics, Vol. 7, No. 4, pp. 1136-1142, 2017. 10.1109/JPHOTOV.2017.2699860

21. T. J. Silverman, L. Mansfield, I. Repins, and S. Kurtz, "Damage in Monolithic Thin-Film Photovoltaic Modules Due to Partial Shade," IEEE Journal of Photovoltaics, Vol. 6, No. 5, pp. 1333-1338, 2016. http://dx.doi.org/10.1109/JPHOTOV.2016.2591330

22. J. E. Lee, S. Bae, W. Oh, H. Park, S. M. Kim, D. Lee, J. Nam, C. B. Mo, D. Kim, J. Yang, Y. Kang, H.-S. Lee, and D. Kim, "Investigation of damage caused by partial shading of CulnxGa(1-x)Se2 photovoltaic modules with bypass diodes," Progress in Photovoltaics: Research and Applications, Vol. 24, No. 8, pp. 1035-1043, 2016. http://dx.doi.org/10.1002/pip.2738

23. M. Nardone, S. Dahal, and J. M. Waddle, "Shading-induced failure in thin-film photovoltaic modules: Electrothermal simulation with nonuniformities," Solar Energy, Vol. 139, pp. 381-388, 2016. 10.1016/j.solener.2016.10.006

24. K. Sakurai, H. Tomita, D. Schmitz, S. Tokuda, K. Ogawa, H. Shibata, and A. Masuda, "Exploring suitable damp heat and potential induced degradation test procedures for $\mathrm{Cu}(\mathrm{In}, \mathrm{Ga})(\mathrm{S}, \mathrm{Se})$ photovoltaic modules," Japanese Journal of Applied Physics, Vol. 57, No. 8, 2018. 10.7567/JJAP.57.08RG02

25. S. Keiichiro, T. Hiroshi, S. Darshan, T. Shuuji, O. Kinichi, S. Hajime, and M. Atsushi, "Exploring suitable damp heat and potential induced degradation test procedures for 
$\mathrm{Cu}(\mathrm{In}, \mathrm{Ga})(\mathrm{S}, \mathrm{Se})$ photovoltaic modules," Japanese Journal of Applied Physics, Vol. 57, No. 8S3, pp. 08RG02, 2018. http://dx.doi.org/doi.org/10.7567/JJAP.57.08RG02

26. S. Boulhidja, A. Mellit, and S. Voswinckel, "Potential-induced degradation test on CIGS photovoltaic modules," Paper in 2017 5th International Conference on Electrical Engineering - Boumerdes, ICEE-B 2017, Vol. 2017-January, pp. 1-4,

27. N. A. Olsson, M. Propst, C. Richardson, and J. Hevelone, "Thin Film PID Field Failures and Root Cause Determination," Paper in Conference Record of the IEEE Photovoltaic Specialists Conference, Vol. 2016 October, pp. 3428-3431,

28. W. Luo, Y. S. Khoo, P. Hacke, V. Naumann, D. Lausch, S. P. Harvey, J. P. Singh, J. Chai, Y. Wang, A. G. Aberle, and S. Ramakrishna, "Potential-induced degradation in photovoltaic modules: A critical review," Energy and Environmental Science, Vol. 10, No. 1, pp. 43-68, 2017. http://dx.doi.org/10.1039/c6ee02271e

29.P. Hacke, S. Spataru, S. Johnston, K. Terwilliger, K. Vansant, M. Kempe, J. Wohlgemuth, S. Kurtz, A. Olsson, and M. Propst, "Elucidating PID Degradation Mechanisms and in Situ Dark I-V Monitoring for Modeling Degradation Rate in CdTe Thin-Film Modules," IEEE Journal of Photovoltaics, Vol. 6, No. 6, pp. 1635-1640, 2016. 10.1109/JPHOTOV.2016.2598269

30. M. C. Alonso-Garcia, P. Hacke, S. Glynn, C. P. Muzzillo, and L. M. Mansfield, "Analysis of Potential-Induced Degradation in Soda-Lime Glass and BorosilicateGlass $\mathrm{Cu}(\mathrm{In}, \mathrm{Ga}) \mathrm{Se}_{2}$ Samples," IEEE Journal of Photovoltaics, 2018. Submitted.

31. M. Powalla, G. Voorwinden, D. Hariskos, P. Jackson, and R. Kniese, "Highly efficient CIS solar cells and modules made by the co-evaporation process," Thin Solid Films, Vol. 517, No. 7, pp. 2111-2114, 2009. https://doi.org/10.1016/j.tsf.2008.10.126

32. N. Naghavi, S. Temgoua, T. Hildebrandt, J. F. Guillemoles, and D. Lincot, "Impact of oxygen concentration during the deposition of window layers on lowering the metastability effects in $\mathrm{Cu}(\mathrm{In}, \mathrm{Ga}) \mathrm{Se}_{2} / \mathrm{CBD} \mathrm{Zn}(\mathrm{S}, \mathrm{O})$ based solar cell," Progress in Photovoltaics: Research and Applications, Vol. 23, No. 12, pp. 1820-1827, 2015. https://doi.org/10.1002/pip.2626

33. J. Serhan, Z. Djebbour, W. Favre, A. Migan-Dubois, A. Darga, D. Mencaraglia, N. Naghavi, G. Renou, J. F. Guillemoles, and D. Lincot, "Investigation of the metastability behavior of CIGS based solar cells with $\mathrm{ZnMgO}-\mathrm{Zn}(\mathrm{S}, \mathrm{O}, \mathrm{OH})$ window-buffer layers," Thin Solid Films, Vol. 519, No. 21, pp. 7606-7610, 2011. http://dx.doi.org/10.1016/j.tsf.2010.12.148

34. K. Kushiya and $\mathrm{O}$. Yamase, "Stabilization of $\mathrm{PN}$ heterojunction between $\mathrm{Cu}(\mathrm{InGa}) \mathrm{Se}_{2}$ thin-film absorber and $\mathrm{ZnO}$ window with $\mathrm{Zn}(\mathrm{O}, \mathrm{S}, \mathrm{OH}) \times$ buffer," Japanese Journal of Applied Physics, Part 1: Regular Papers and Short Notes and Review Papers, Vol. 39, No. 5 A, pp. 2577-2582, 2000.

35. J. Pettersson, C. Platzer-Björkman, and M. Edoff, "Temperature-dependent currentvoltage and lightsoaking measurements on $\mathrm{Cu}(\mathrm{In}, \mathrm{Ga}) \mathrm{Se}_{2}$ solar cells with ALD-Zn 1 xMgxO buffer layers," Progress in Photovoltaics: Research and Applications, Vol. 17, No. 7, pp. 460-469, 2009. https://doi.org/10.1002/pip.912

36. M. Burgelman, P. Nollet, and S. Degrave, "Modelling polycrystalline semiconductor solar cells," Thin Solid Films, Vol. 361-362, pp. 527-532, 2000. https://doi.org/10.1016/S0040-6090(99)00825-1 
37. I. L. Repins, S. Harvey, K. Bowers, S. Glynn, and L. M. Mansfield, "Predicting Ga and $\mathrm{Cu}$ profiles in co-evaporated $\mathrm{Cu}(\mathrm{In}, \mathrm{Ga}) \mathrm{Se}_{2}$ using modified diffusion equations and a spreadsheet," MRS Advances, pp. 1-6, 2017. http://dx.doi.org/10.1557/adv.2017.350

38. M. Schmid, "Review on light management by nanostructures in chalcopyrite solar cells," Semiconductor Science and Technology, Vol. 32, No. 4, 2017. https://doi.org/10.1088/1361-6641/aa59ee

39. L. M. Mansfield, A. Kanevce, S. P. Harvey, K. Bowers, C. Beall, S. Glynn, and I. L. Repins, "Efficiency increased to $15.2 \%$ for ultra-thin $\mathrm{Cu}(\mathrm{In}, \mathrm{Ga}) \mathrm{Se}_{2}$ solar cells," Progress in Photovoltaics: Research and Applications, Vol. 26, No. 11, pp. 949-954, 2018. https://doi.org/10.1002/pip.3033

40. S. Puttnins, S. Jander, A. Wehrmann, G. Benndorf, M. Stölzel, A. Müller, H. von Wenckstern, F. Daume, A. Rahm, and M. Grundmann, "Breakdown characteristics of flexible $\mathrm{Cu}(\mathrm{In}, \mathrm{Ga}) \mathrm{Se}_{2}$ solar cells," Solar Energy Materials and Solar Cells, Vol. 120, Part B, pp. 506-511, 2014. http://dx.doi.org/10.1016/j.solmat.2013.09.031

41. C. P. Muzzillo, "Review of grain interior, grain boundary, and interface effects of $\mathrm{K}$ in CIGS solar cells: Mechanisms for performance enhancement," Solar Energy Materials and Solar Cells, Vol. 172, pp. 18-24, 2017. http://dx.doi.org/10.1016/j.solmat.2017.07.006

42. M. A. Contreras, P. Hacke, and I. Repins, "Development of $\mathrm{Cu}(\mathrm{In}, \mathrm{Ga}) \mathrm{Se}_{2}$ test coupons for potential induced degradation studies," Paper in 2016 IEEE 43rd Photovoltaic Specialists Conference (PVSC), Portland, OR, 5-10 June 2016, pp. 0857-0862,

43. C. P. Muzzillo, S. Glynn, P. Hacke, H. R. Moutinho, M. R. Young, G. Teeter, I. L. Repins, and L. M. Mansfield, "Potential-Induced Degradation of $\mathrm{Cu}(\mathrm{In}, \mathrm{Ga}) \mathrm{Se}_{2}$ Solar Cells: Alkali Metal Drift and Diffusion Effects," IEEE Journal of Photovoltaics, Vol. 8, No. 5, pp. 1337-1342, 2018. http://dx.doi.org/10.1109/JPHOTOV.2018.2858549

44. V. Fjallstrom, P. M. P. Salome, A. Hultqvist, M. Edoff, T. Jarmar, B. G. Aitken, K. Zhang, K. Fuller, and C. K. Williams, "Potential-induced degradation of Culn $1-x \mathrm{Ga}_{\times} \mathrm{Se}_{2}$ thin film solar cells," IEEE Journal of Photovoltaics, Vol. 3, No. 3, pp. 1090-1094, 2013. http://dx.doi.org/10.1109/JPHOTOV.2013.2253833 